\title{
Carbonyl sulfide exchange in a temperate loblolly pine forest grown under ambient and elevated $\mathrm{CO}_{2}$
}

\author{
M. L. White, Y. Zhou, R. S. Russo, H. Mao, R. Talbot, R. K. Varner, and B. C. Sive \\ Climate Change Research Center, Institute for the Study of Earth, Oceans, and Space, University of New Hampshire, \\ Durham, NH 03824, USA
}

Received: 19 July 2009 - Published in Atmos. Chem. Phys. Discuss.: 14 August 2009

Revised: 13 December 2009 - Accepted: 16 December 2009 - Published: 21 January 2010

\begin{abstract}
Vegetation, soil and ecosystem level carbonyl sulfide (COS) exchange was observed at Duke Forest, a temperate loblolly pine forest, grown under ambient (Ring 1, R1) and elevated (Ring 2, R2) $\mathrm{CO}_{2}$. During calm meteorological conditions, ambient COS mixing ratios at the top of the forest canopy followed a distinct diurnal pattern in both $\mathrm{CO}_{2}$ growth regimes, with maximum COS mixing ratios during the day $(\mathrm{R} 1=380 \pm 4 \mathrm{pptv}$ and R2 $=373 \pm 3$ pptv, daytime mean \pm standard error) and minimums at night $(\mathrm{R} 1=340 \pm 6 \mathrm{pptv}$ and $\mathrm{R} 2=346 \pm 5 \mathrm{pptv}$, nighttime mean \pm standard error) reflecting a significant nighttime sink. Nocturnal vegetative uptake $(-11$ to $-21 \mathrm{pmol} \mathrm{m}^{-2} \mathrm{~s}^{-1}$, negative values indicate uptake from the atmosphere) dominated nighttime net ecosystem COS flux estimates $\left(-10\right.$ to $\left.-30 \mathrm{pmol} \mathrm{m}^{-2} \mathrm{~s}^{-1}\right)$ in both $\mathrm{CO}_{2}$ regimes. In comparison, soil uptake $\left(-0.8\right.$ to $\left.-1.7 \mathrm{pmol} \mathrm{m}^{-2} \mathrm{~s}^{-1}\right)$ was a minor component of net ecosystem COS flux. In both $\mathrm{CO}_{2}$ regimes, loblolly pine trees exhibited substantial COS consumption overnight (50\% of daytime rates) that was independent of $\mathrm{CO}_{2}$ assimilation. This suggests current estimates of the global vegetative COS sink, which assume that $\mathrm{COS}$ and $\mathrm{CO}_{2}$ are consumed simultaneously, may need to be reevaluated. Ambient COS mixing ratios, species specific diurnal patterns of stomatal conductance, temperature and canopy position were the major factors influencing the vegetative COS flux at the branch level. While variability in branch level vegetative $\mathrm{COS}$ consumption measurements in ambient and enhanced $\mathrm{CO}_{2}$ environments could not be attributed to $\mathrm{CO}_{2}$ enrichment effects, estimates of net ecosystem COS flux based on ambient canopy mixing ratio measurements suggest less nighttime uptake of COS in R2, the $\mathrm{CO}_{2}$ enriched environment.
\end{abstract}

Correspondence to: M. L. White (mwhite@gust.sr.unh.edu)

\section{Introduction}

With an atmospheric lifetime of approximately 5 years and an average global mixing ratio of 500 pptv, carbonyl sulfide (COS) is the most abundant sulfur-containing gas in the troposphere (Chin and Davis, 1995; Notholt et al., 2003) and the most important sulfur gas available for transport to the stratosphere (Chin and Davis, 1995). Once there, COS photolysis and oxidation contribute to the formation of the stratospheric sulfate aerosol layer; this aerosol layer influences the Earth's radiation balance by reflecting incoming solar radiation (Turco et al., 1980) and provides a surface for heterogeneous ozone depletion reactions (Solomon et al., 1996).

Terrestrial ecosystems play a major role in the global COS budget as vegetative uptake is the largest global sink for the gas (Brown and Bell, 1986; Goldan et al., 1988; Kjellstrom, 1998; Kettle et al., 2002) while microbial consumption in soils is the second largest (Kesselmeier et al., 1999; Kettle et al., 2002). Oceanic emissions, including both indirect production from the oxidation of marine emissions of carbon disulfide $\left(\mathrm{CS}_{2}\right)$ and dimethyl sulfide (DMS) (Barnes et al., 1994; Chin and Davis, 1993) and direct COS photochemical production from dissolved organic matter (Weiss et al., 1995), are the major COS sources to the troposphere. Additionally, biomass burning and anthropogenic activities such as aluminum production and coal combustion are significant terrestrial sources of COS (Chin and Davis, 1993; Kettle, 2000).

Currently, the magnitude of the natural vegetative and soil sinks is poorly constrained. For example, observations of seasonal variations in $\operatorname{COS}$ mixing ratios at a variety of Northern Hemisphere surface sites appear to be much larger than can be explained by current estimates of the COS vegetative sink (Montzka et al., 2007). Since the same enzymes that utilize $\mathrm{CO}_{2}$ during photosynthesis also consume $\mathrm{COS}$ (Protoschill-Krebs and Kesselmeier, 1992), the global COS

Published by Copernicus Publications on behalf of the European Geosciences Union. 
vegetation sink has been calculated by scaling estimates of net primary production (NPP) by the ratio of the mean mixing ratios of $\mathrm{COS}$ and $\mathrm{CO}_{2}$ (Kjellstrom, 1998; Kettle et al., 2002; Goldan et al., 1988). However, a variety of studies have indicated that $\mathrm{COS}$ uptake by plants is favored over $\mathrm{CO}_{2}$ (Xu et al., 2002; Sandoval-Soto et al., 2005; Geng and Mu, 2006; Montzka et al., 2007). This reflects the higher affinity of carbonic anhydrase, the initial photosynthetic enzyme for COS (Protoschill-Krebs et al., 1996), the irreversible hydrolysis of COS compared to $\mathrm{CO}_{2}$ (Elliot et al., 1989), and respiration (Sandoval-Soto et al., 2005). In support of this, a recent modeling study using gross primary production (GPP) to estimate COS flux was able to accurately represent continental scale COS variability over the United States compared to models based on NPP estimates (Campbell et al., 2008).

Initially, soils were considered sources of COS to the atmosphere (e.g. Aneja et al., 1979). However, this conclusion was based upon soil fluxes measured using dynamic chambers swept with S-free air. Under these conditions, an artificial gradient of COS within the chamber often forced soil emission of COS (Castro and Galloway, 1991). More recent studies using enclosures flushed with ambient air have revealed that most soils actually consume COS (Kuhn et al., 1999; Simmons et al., 1999; Yi et al., 2007; Steinbacher et al., 2004; deMello and Hines, 1994). However, the environmental controls over soil uptake processes were highly variable between sites and soil types. As a result, estimates of the global soil sink strength have a wide range of uncertainty (Watts, 2000; Kettle et al., 2002).

The potential effect of rising $\mathrm{CO}_{2}$ levels on COS consumption in terrestrial ecosystems is also currently unclear. Evidence indicates that elevated $\mathrm{CO}_{2}$ levels can increase forest NPP (Norby et al., 2005) although interactions with other biophysical factors within the ecosystem make long-term effects on NPP uncertain (Bonan, 2008). The warmer temperatures associated with higher $\mathrm{CO}_{2}$ levels have also increased growing seasons in boreal and temperate forests suggesting an enhanced vegetation sink for COS (Norby et al. 2003, Steltzer and Post, 2009; Zhou et al., 2001, 2003). However, laboratory studies indicate that the rate of COS consumption drops with the decreased expression of the photosynthetic enzyme carbonic anhydrase in algae grown under elevated $\mathrm{CO}_{2}$ (Protoschill-Krebs et al., 1995). For many plant species, COS uptake is also largely controlled by stomatal conductance (Geng and Mu, 2006; Sandoval-Soto et al., 2005) and there is evidence that enhanced $\mathrm{CO}_{2}$ conditions will result in reduced stomatal conductance and frequency for many plant species, potentially further limiting the COS plant sink (Herrick et al., 2004; Kouwenberg et al., 2003; Kurschner et al., 1997; Greenwood et al., 2003; Wagner et al., 2005; Lake and Woodward, 2008). In many cases, changes in stomatal conductance impact transpiration in plants exposed to elevated $\mathrm{CO}_{2}$ resulting in increased soil moisture (Kettunen et al., 2006; Kammann et al., 2005; Hungate et al., 2002; McLain et al., 2002). Such changes could have a significant impact on soil COS consumption which is a microbial process dependent on moisture content, temperature, and ambient COS concentrations (Kesselmeier et al., 1999).

We present measurements made at the Duke Forest (DF) Free Atmospheric Carbon Enrichment (FACE) site, which offered a unique opportunity to examine the magnitude and controls of vegetative and soil COS uptake in a temperate forest grown under present day and elevated $\mathrm{CO}_{2}\left(200 \mu \mathrm{LL}^{-1}\right.$ higher than ambient) conditions (http://face.env.duke.edu/ main.cfm). Considering the limited number of field studies of COS exchange at the ecosystem level, these measurements also provide considerable insights into the natural variability of COS consumption processes and their impact on ambient COS mixing ratios. Measurements were made of ambient canopy COS levels and vegetation and soil fluxes within control (ambient $\mathrm{CO}_{2}$ ) and $\mathrm{CO}_{2}$ enriched plots at DF in 2004 and 2005. This study presents an analysis of the diel cycles and major factors influencing COS consumption processes within the two $\mathrm{CO}_{2}$ regimes. Estimates of net ecosystem COS flux were also made and compared to measured vegetation and soil fluxes to better understand the impacts of individual sinks on COS uptake at the site.

\section{Methods}

The measurements presented here are from three field studies conducted at the Duke Forest FACE site in September 2004 and June and September 2005. Descriptions of the significant measurements and calculations from each study are presented below. All data is presented in local time (LT), which is UTC-04:00. All means are presented as mean \pm standard error unless otherwise indicated. Statistical analyses were conducted using SPSS v. 15.0.1.1. (SPSS, Inc.).

\subsection{Site description}

The Duke Forest FACE site $\left(35^{\circ} 52^{\prime} \mathrm{N}, 79^{\circ} 59^{\prime} \mathrm{W}\right)$ is a loblolly pine (Pinus taeda) stand located in Chapel Hill in the central Piedmont region of North Carolina at the ForestAtmosphere Carbon Transfer and Storage (FACTS-1) facility. Pine trees dominate the forest canopy with significant subcanopy and understory contributions from deciduous sweetgum (Liquidambar styraciflua), elm (Ulmus alata), red maple (Acer rubrum), dogwood (Cornus florida) and a variety of oak-hickory species. The soils are classified as Enon series (fine, mixed, weathered alfisols) (Oh and Richter, 2005).

The FACE experiment consists of 6 circular experimental plots, or rings, each $30 \mathrm{~m}$ in diameter and surrounded by vertical vent pipes that extend to the top of the canopy. Three experimental rings receive additional $\mathrm{CO}_{2}$ through the vent pipes to supplement atmospheric concentrations by $200 \mu \mathrm{LL}^{-1}$. The remaining three control rings are exposed to ambient $\mathrm{CO}_{2}$ concentrations. Continuous $\left(24 \mathrm{~h} \mathrm{~d}^{-1}\right.$, 
$\left.365 \mathrm{~d} \mathrm{yr}^{-1}\right) \mathrm{CO}_{2}$ fumigation began on 27 August 1996. Since 2003, fumigation has been limited to daylight hours only. In 2005, both control and treatment plots were split into two halves with one half of the ring receiving nitrogen $(\mathrm{N})$ fertilization at a rate of $11.2 \mathrm{~g} \mathrm{~N} \mathrm{~m}^{-2} \mathrm{yr}^{-1}$ (Schafer et al., 2002).

All measurements described here were collected within Ring 1 (R1, control) and Ring $2\left(\mathrm{R} 2,+200 \mu \mathrm{LL}^{-1} \mathrm{CO}_{2}\right)$. All soil and vegetation flux measurements were made within the unfertilized halves of these two rings.

\subsection{Canopy measurements, September 2004}

Hourly air samples were collected in 2-liter electropolished stainless steel canisters and pressurized to 35 psig using a single head metal bellows pump (MB-302MOD, Senior Flexonics, Sharon, MA) from 15-28 September 2004. The canister samples were collected simultaneously in R1 and R2 from inlets at $16 \mathrm{~m}$ above ground (tree canopy height) on the central monitoring tower within each ring. All samples were returned to the University of New Hampshire (UNH) and analyzed within two weeks of collection on a three GC system equipped with two flame ionization detectors (FIDs), two electron capture detectors (ECDs), and a mass spectrometer (MS) for $\mathrm{C}_{2}-\mathrm{C}_{10}$ nonmethane hydrocarbons (NMHCs), $\mathrm{C}_{1}-\mathrm{C}_{2}$ halocarbons, $\mathrm{C}_{1}-\mathrm{C}_{5}$ alkyl nitrates, and select oxygenated volatile organic compounds (OVOCs) and organic sulfur compounds including COS, carbon disulfide $\left(\mathrm{CS}_{2}\right)$ and dimethyl sulfide (DMS)(Sive et al., 2005, 2007; Zhou et al., 2005, 2008).

Carbon dioxide was sampled from 11-28 September simultaneously at the $16 \mathrm{~m}$ sampling height in R1 and R2 using LiCor 7000 infrared gas analyzers. Mixing ratios were measured every $5 \mathrm{~s}$ and averaged over one-minute intervals. Wind speed and direction, air temperature and photosynthetically active radiation (PAR) were collected at one minute intervals by the FACTS-I meteorological instruments in R2. The Climatronics F460 anemometer and wind vane and LiCor quantum sensor were mounted above the tree canopy, while air temperature was collected using thermocouples mounted within the mid-canopy. Meteorological data were averaged hourly to facilitate comparison to volatile organic compound (VOC) measurements. Precipitation data for the FACE site was collected on a daily basis from the FACTS-I rain gauge.

\subsection{Vertical profile measurements, September 2004 and June 2005}

Vertical profiles of VOC mixing ratios from ground level to above the canopy were also measured on four occasions during the September 2004 and June 2005 field campaigns. During each profile measurement, evacuated canisters were filled to ambient pressure at 5 height intervals from $1 \mathrm{~m}$ to $20 \mathrm{~m}$ above ground in each ring. During 2004, profiles in R1 and R2 were obtained on 26 September at 18:00 LT. During 2005, profiles were obtained in all 6 experimental rings (R1, R5, $\mathrm{R} 6=$ ambient $\mathrm{CO}_{2} ; \mathrm{R} 2, \mathrm{R} 3, \mathrm{R} 4=+200 \mu \mathrm{LL}^{-1} \mathrm{CO}_{2}$ ) on 5 June at 15:00 LT. Additional profile measurements were made in R1 and R2 on 6 June 2005 at 00:30 LT and 10 June 2005 at 16:00 LT. All canisters were returned to UNH and analyzed within two weeks of collection on the GC system described above.

\subsection{Vegetation flux measurements, June 2005}

During the second field campaign (1-12 June 2005), direct vegetation VOC fluxes were measured within R1 and R2 (Sive et al., 2007). Vegetation flux measurements were collected approximately every two hours for loblolly pine and sweetgum, the two dominant trees at the site, over two 48-hour sampling periods using dynamic branch enclosures. The enclosures were made of large clear Teflon bags supported by an external frame. A single tree branch was placed within the enclosure and exposed to a continuous flow of air from the canopy to maintain ambient pressure. A mass flow meter continuously monitored the rate of air flow into the bag (3-6 $\mathrm{L} \mathrm{min}^{-1}$ ) while a cold palladium catalyst was used for ozone $\left(\mathrm{O}_{3}\right)$ removal. In addition to $\mathrm{O}_{3}$, the palladium catalyst also removed a fraction of $\mathrm{COS}(0-400 \mathrm{pptv})$ and $\mathrm{CO}_{2}$ $(0-170 \mathrm{ppmv})$ from the ambient canopy air pumped into the bag. A more detailed description of the effect of catalyst COS depletion on flux measurements is given in Sect. 3.3.1. Air from the enclosure was vented through the outlet located deep within the bag to ensure that samples were well-mixed. Branches were enclosed and exposed to $\mathrm{O}_{3}$ scrubbed canopy air for $24 \mathrm{~h}$ prior to sampling. Temperature, relative humidity, and photosynthetically active radiation (PAR) within the bag were monitored continuously using thermocouples, relative humidity sensors, and photodiodes mounted on the branch sampled.

During each flux measurement, three air samples were collected: ambient (A) air from the canopy drawn from the initial air intake, post-catalyst (PC) air sampled from the air flow entering the bag, and bag (B) air sampled from the outlet vent. The sampling flow rate was controlled using a needle valve to make sure that positive outlet vent pressure was maintained continuously. Air samples were collected for VOC analysis as described above in 2-liter electropolished stainless steel canisters and pressurized to $35 \mathrm{psig}$. A LiCor 7000 infrared gas analyzer and a miniature $\mathrm{O}_{3}$ sensor (Mao et al., 2006) attached to the sampling manifold monitored $\mathrm{CO}_{2}$ and $\mathrm{O}_{3}$ levels in the sampled air flow. Flux measurements were made every $2 \mathrm{~h}$ from $4-6$ June 2005 for the loblolly pines and 8-10 June 2005 for the sweetgum trees. After sampling, the branch enclosed was removed from the tree and returned to UNH for direct measurement of leaf dry weight and leaf area.

Vegetation fluxes ( $\mathrm{pmol} \mathrm{m}^{-2} \mathrm{LA} \mathrm{s}^{-1}$ ) were calculated for $\mathrm{COS}$ and $\mathrm{CO}_{2}$ as follows:

Flux $=\left[C_{\mathrm{B}}-C_{\mathrm{PC}}\right] \cdot$ flow $\cdot \mathrm{LA}^{-1}$ 
where $C$ is the concentration of $\mathrm{COS}$ and $\mathrm{CO}_{2}$ in pmol m $\mathrm{m}^{-3}$ and $\mu \mathrm{mol} \mathrm{m}{ }^{-3}$, respectively, in both the bag (B) and postcatalyst (PC) air samples, flow is the rate of air flow into the bag in $\mathrm{m}^{3} \mathrm{~s}^{-1}$, and LA represents the single sided leaf area $\left(\mathrm{m}^{2}\right)$ of the enclosed branch. Flux errors were propagated as described by Taylor (1982) from individual measurement uncertainties for $\operatorname{COS}(5 \%), \mathrm{CO}_{2}(5 \%)$, leaf area $(10 \%)$, and the standard error of the mean inlet flow rate during measurement $(2 \%)$.

\subsection{Soil flux measurements, June and September 2005}

Soil fluxes were measured within Ring 1 and 2 on 9 June and 20 September 2005 using static enclosures as described in Varner et al. (1999). Measurements were made using four $30 \mathrm{~cm} \times 30 \mathrm{~cm}$ Teflon coated aluminum collars placed in the soil a month prior to field sampling. Two collars (labeled R1 collar A, R1 collar B, R2 collar A, and R2 collar B) were placed in both rings. During sampling, a Teflon coated aluminum chamber (30 L volume) was placed over each collar for approximately $30 \mathrm{~min}$. An ambient pressure canister sample was collected from the chamber headspace every 10 to $12 \mathrm{~min}$ for a total of 4 samples. On both 9 June and 20 September, all soil measurements were collected between 08:00 and 19:00 local time with each collar being sampled 3 to 4 times throughout the day. Canister air samples were returned to UNH for VOC analysis as described above.

Chamber and soil temperatures at 0,5 and $10 \mathrm{~cm}$ depths were measured each time a collar was sampled. Additionally, soil moisture data for 9 June and 20 September 2005 was obtained from the FACTS- 1 time-domain reflectometry (TDR) instruments established in R1 and R2. (FACTS-1, 2006b). Half-hourly soil moisture values for each ring were calculated as the average of half-hourly measurements recorded by the four TDR instruments located within each plot.

Soil fluxes $\left(\mathrm{pmol} \mathrm{m}^{-2} \mathrm{~s}^{-1}\right)$ were calculated as the initial change in chamber COS concentration vs. time, $\left(\frac{\mathrm{d} C}{\mathrm{~d} t}\right)_{t=0}$, in pmol $\mathrm{m}^{-3} \mathrm{~s}^{-1}$ multiplied by the chamber volume, $V_{\mathrm{c}}\left(\mathrm{m}^{3}\right)$, and divided by collar area, $A_{\mathrm{c}}\left(\mathrm{m}^{2}\right)$ :

Flux $=\left(\frac{\mathrm{d} C}{\mathrm{~d} t}\right)_{t=0} \cdot \frac{V_{\mathrm{c}}}{A_{\mathrm{c}}}$

In 11 of the 30 soil flux measurements made in June and September 2005, the change in chamber concentration was linear over the time of chamber deployment. In these cases, $\left(\frac{\mathrm{d} C}{\mathrm{~d} t}\right)_{t=0}$ was calculated as the linear regression slope of chamber concentration versus time. In the remaining 19 soil flux measurements, the rate of change in chamber concentration decreased with time and $\left(\frac{\mathrm{d} C}{\mathrm{~d} t}\right)_{t=0}$ was calculated by fitting the following exponential equation to the data (deMello and Hines, 1994):

$C(t)=a-b \cdot e^{(-k t)}$ where, " $a$ " was $C_{\mathrm{eq}}$, or the concentration reached when $\operatorname{COS}$ within the chamber reached equilibrium with the concentration in soil micropores, " $b$ " was $C_{\text {eq }}$ minus $C_{t=0}$, the COS concentration at $t=0$, and $k$ is a rate constant. The values of a and $k$ were calculated iteratively for each flux measurement and used to determine $\left(\frac{\mathrm{d} C}{\mathrm{~d} t}\right)_{t=0}$ as follows:

$\left(\frac{\mathrm{d} C}{\mathrm{~d} t}\right)_{t=0}=k \cdot\left(C_{\mathrm{eq}}-C_{t=0}\right)=k \cdot b$

This value for $\left(\frac{\mathrm{d} C}{\mathrm{~d} t}\right)_{t=0}$ was then used in Eq. (2) to calculate net COS flux.

Soil flux errors were propagated as described by Taylor (1982) from the standard errors for the linear regression slope or non linear coefficients, $k$ and a, used during flux calculation as well as the individual measurement uncertainties for the chamber volume (2\%), collar area $(2 \%)$ and COS mixing ratios $(5 \%)$.

\subsection{Estimates of net ecosystem COS uptake rates, September 2004 and June 2005}

Net ecosystem COS uptake rates were calculated from changes in ambient canopy mixing ratios under stable nocturnal boundary layer conditions. This approach for calculating ecosystem COS flux was employed by Kuhn et al. (1999) in a temperate oak forest and has been used in a variety of studies on other trace gases (e.g. Talbot et al., 2005; Zhou et al., 2005; White et al., 2008; Sive et al., 2007; Varner et al., 2008). Under stagnant wind conditions associated with the stable boundary layer, changes in ambient mixing ratios should reflect local sources and sinks. As a result, net nighttime fluxes, NF, can be estimated as:

$\mathrm{NF}\left(\mathrm{pmol} \mathrm{m}^{-2} \mathrm{~s}^{-1}\right)=\frac{\mathrm{d} C}{\mathrm{~d} t} \cdot \mathrm{ML}$

Where $\frac{\mathrm{d} C}{\mathrm{~d} t}$ is the change in concentration over time (pmol m${ }^{-3} \mathrm{~s}^{-1}$ ) and $\mathrm{ML}$ is the height of the mixed layer (m).

Only measurements taken when wind speeds were $\leq 0.8 \mathrm{~m} \mathrm{~s}^{-1}$ were used to calculate NF to limit the influence of large-scale horizontal advection on our flux estimates. Unfortunately, only one night during each campaign met these conditions (15-16 September 2004 and 4-5 June 2005). As nocturnal mixing layer height was not measured during either campaign, ML height was assumed to be $125 \mathrm{~m}$, which represents the median value of the nocturnal inversion layer height range $(50-200 \mathrm{~m})$ measured at a variety of similar midlatitudinal rural locations (Galbally, 1968; Güsten et al., 1998; Hastie et al., 1993; Shepson et al., 1992). Concentration changes were not linear over time and individual fluxes were calculated for each hour time step. Flux errors were propagated from the individual measurement uncertainties in the canopy COS measurements $(5 \%)$ and the estimated uncertainty in the ML height (60\%) according to Taylor (1982). 
(a)

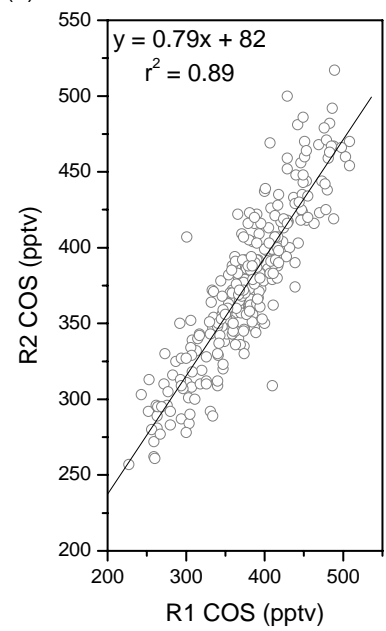

(b)

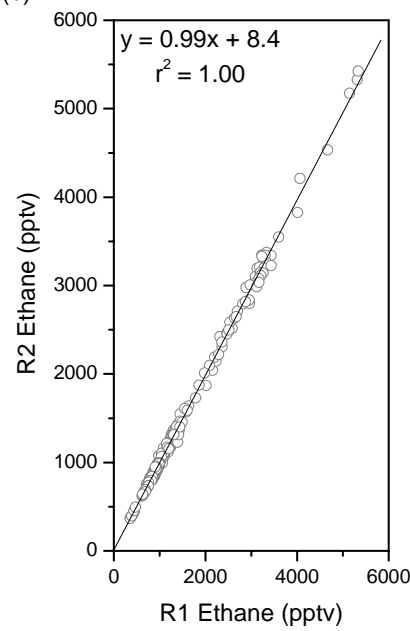

Fig. 1. A comparison of R1 and R2 (a) COS and (b) ethane ambient mixing ratios at $16 \mathrm{~m}$ above ground from 15-28 September 2004 .

For comparison, total vegetation and soil fluxes scaled to ground area were also estimated for both nights. The vegetation fluxes were calculated as follows:

VegFlux $=-V_{\mathrm{d}, \mathrm{veg}} \cdot \mathrm{LAI} \cdot A_{\mathrm{COS}}$

where $V_{\mathrm{d} \text {,veg }}$ is the mean nighttime deposition velocity $\left(\mathrm{m} \mathrm{s}^{-1}\right)$ for LP and SG trees measured in each ring in June 2005, LAI is the mean single sided leaf area index $\left(\mathrm{m}^{2} \mathrm{LA} \mathrm{m}^{-2} \mathrm{GA}\right)$ during September 2004 or June 2005, and $A_{\mathrm{COS}}$ is the mean nighttime ambient COS levels in pmol m $\mathrm{m}^{-3}$ during 15-16 September 2004 and 4-5 June 2005. Deposition velocities, $V_{\mathrm{d}}$, were calculated from the absolute value of measured nighttime vegetation flux rates divided by postcatalyst (PC) COS mixing ratios at the time of measurement. The LAI measurements for R1 and R2 canopies were taken from FACTS-1 Li-Cor LAI-2000 plant canopy analyzer monthly measurements (FACTS-1, 2006a). These were corrected for needle clumping and branch shading by multiplying by an enhancement factor of $1.9 \pm 0.6$, the mean value of the range of coniferous tree LAI enhancement factors (1.25 to 2.5) noted in Stenberg (1996).

Similarly, soil flux rates were calculated for 1516 September 2004 and 4-5 June 2005 as follows:

SoilFlux $=-V_{\mathrm{d}, \text { soil }} \cdot A_{\mathrm{COS}}$

The mean September 2005 soil deposition velocities, $V_{\mathrm{d} \text {,soil }}$, in each ring were used for the night of 15-16 September 2004 while the mean June $2005 V_{\text {d, soil }}$ were used for the night of 45 June 2005. Errors for both fluxes were propagated from the standard errors of the means used in calculation as described by Taylor (1982).
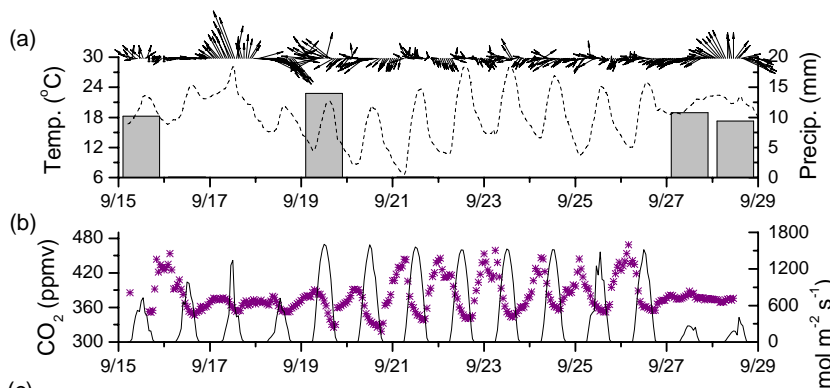

(c)

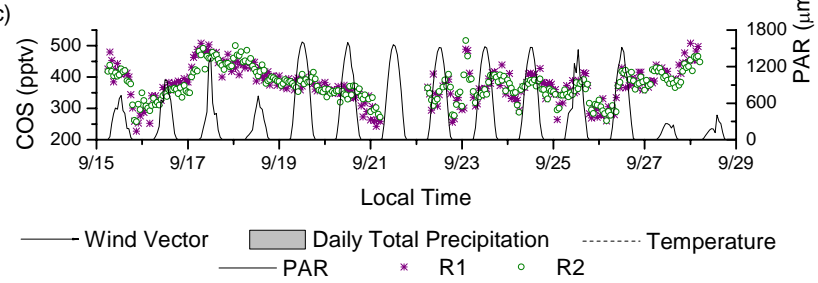

Fig. 2. Select canopy measurements made at $16 \mathrm{~m}$ above ground in September 2004 including (a) air temperature, wind speed (displayed as vector) and total daily precipitation; (b) ambient $\mathrm{R} 1 \mathrm{CO}_{2}$ mixing ratios and photosynthetically active radiation (PAR); and (c) $\mathrm{R} 1$ and $\mathrm{R} 2 \mathrm{COS}$ mixing ratios.

\section{Results and discussion}

\subsection{Canopy measurements, September 2004}

Comparison of simultaneous R1 and R2 measurements of $\mathrm{COS}$ and ethane at $16 \mathrm{~m}$ height is presented in Fig. 1 for the entire data collection period. Ethane mixing ratios demonstrate variability between the two rings independent of any natural VOC sources or sinks. This anthropogenic trace gas exhibited a very strong 1:1 relationship indicating minimal variability associated with either ring. In contrast, the R1 versus $\mathrm{R} 2$ relationships for $\mathrm{COS}$ showed much greater scatter that reflects its natural sinks within temperate forests.

The time series of meteorological data, $\mathrm{CO}_{2}$, and $\mathrm{COS}$ measurements conducted at $16 \mathrm{~m}$ height are shown in Fig. 2 for the 2004 intensive. Winds generally originated from the north and east with an average speed throughout the campaign of $1.9 \mathrm{~m} \mathrm{~s}^{-1}$. Exceptions to this pattern occurred during passage of Hurricanes Ivan and Jeanne on 16-19 and 2729 September, respectively, which resulted in revolving wind directions and a maximum wind speed of $11 \mathrm{~m} \mathrm{~s}^{-1}$ (Fig. 2a). Winds from the southeast associated with these hurricanes also coincided with elevated levels of COS indicative of marine influence (Fig. 2a and c). In contrast, moderate wind speeds from the north and east, warm daytime temperatures, and sunny conditions generally prevailed at the site during 21-27 September (Fig. 2a and b). During this time period, ambient $\mathrm{CO}_{2}$ mixing ratios in $\mathrm{R} 1$ followed a pronounced diel pattern with minimum levels in the late afternoon corresponding to photosynthetic uptake and maximum levels overnight.

COS mixing ratios in $\mathrm{R} 1$ and $\mathrm{R} 2$ also exhibited a diel pattern during this time period, although less pronounced 


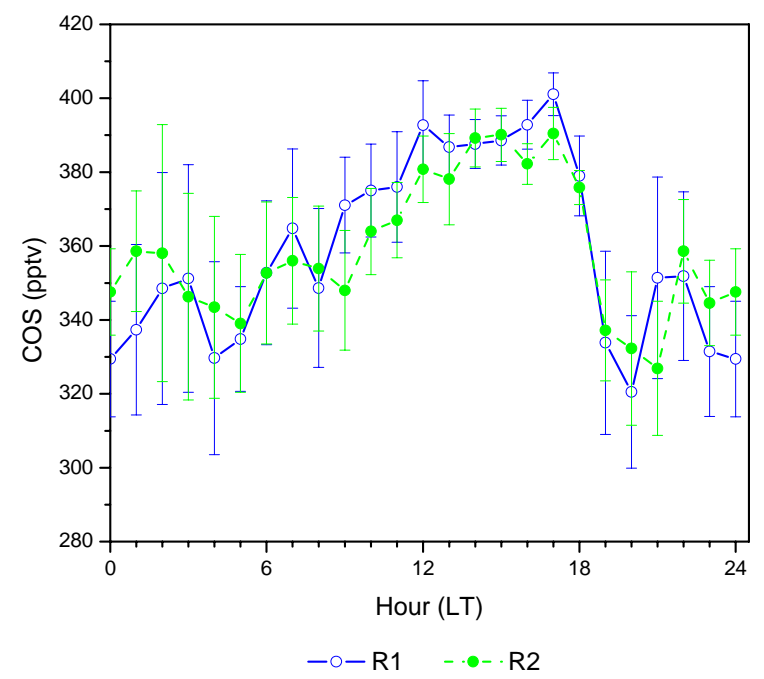

Fig. 3. Hourly mean COS mixing ratios at $16 \mathrm{~m}$ above ground during non-hurricane periods (15-16 and 21-26 September 2004) in R1 and R2. Error bars represent standard error of the mean $(n \geq 6)$

than $\mathrm{CO}_{2}$ and with minimum mixing ratios at night (Figs. $2 \mathrm{c}$ and 3, non-hurricane night means: R1 $=340 \pm 6$ and $\mathrm{R} 2=346 \pm 5$ ). Similar diurnal patterns have been observed in a temperate oak forest in California (Kuhn et al., 1999), a tropical rainforest in Cameroon (Kesselmeier et al., 1993), and a spruce forest in Germany (Steinbacher et al., 2004). The diurnal variability is attributed to a combination of turbulent transport of COS during the day (Kesselmeier et al., 1993) and nighttime depletion under a stable nocturnal boundary layer (Steinbacher et al., 2004; Kuhn et al., 1999). Daytime mixing ratios during non-hurricane periods at DF averaged $380 \pm 4$ pptv in R1 and $373 \pm 3$ pptv in R2, well below the global mean mixing ratio of $500 \mathrm{pptv}$. These lower mixing ratios of COS are consistent with observations at low altitude, Northern Hemisphere continental sites during summer and reflect the influences of a significant vegetation sink (Kuhn et al., 1999; Montzka et al., 2007; Steinbacher et al., 2004).

The lowest COS mixing ratios (R1: 227 pptv, R2: 257 pptv), observed at DF on the night of 15 September, coincided with the lowest wind speeds observed during the study period and further indicate a strong nighttime deposition for this gas to the forest (Fig. 2). From 18:00 to $01: 00 \mathrm{LT}$ that night, $\mathrm{COS}$ mixing ratios in $\mathrm{R} 1$ were also consistently lower than in R2 by 10-60 pptv. Close examination of the hourly mean COS mixing ratios in each ring during non-hurricane periods (15-16 and 21-27 September) revealed that $\operatorname{COS}$ mixing ratios were generally lower overnight (23:00 to 04:00 LT) in R1 than in R2 (Fig. 3). While these differences between the two rings were small on average (0-20 pptv), they do imply that the nighttime COS sink was slightly stronger in R1 than in R2 during September 2004.
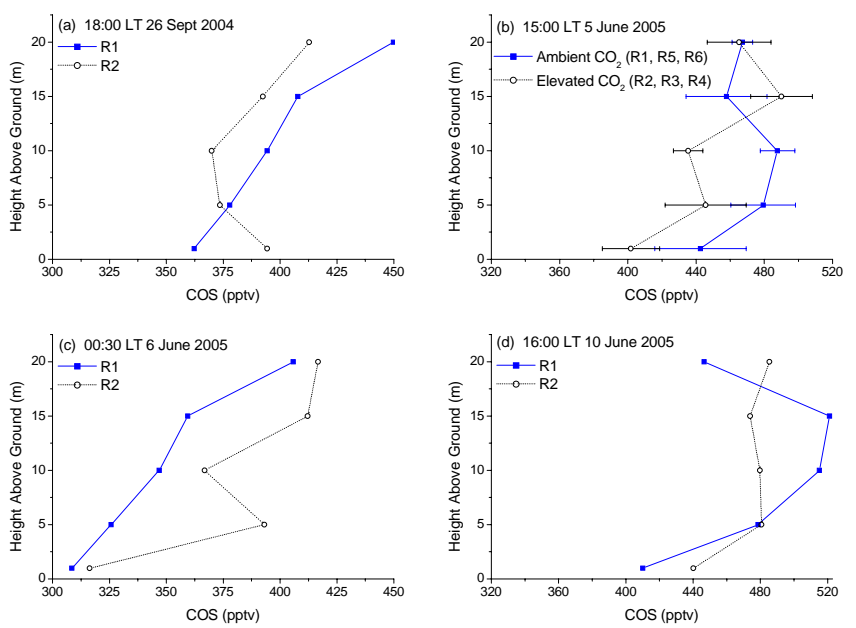

Fig. 4. Ambient COS measurement profiles from ground level (1 m) to above the forest canopy $(20 \mathrm{~m})$ at (a) 18:00 LT on 26 September 2004, (b) 15:00 LT on 5 June 2005; (c) 00:30 LT 6 June 2005; and (d) 16:00 LT 10 June 2005. Error bars on 5c represent standard error of the mean $(n=3)$ at each height within the ambient (R1, R5, R6) and elevated $\mathrm{CO}_{2}(\mathrm{R} 2, \mathrm{R} 3, \mathrm{R} 4)$ rings sampled.

\subsection{Vertical profile measurements, September 2004 and June 2005}

Further support for a forest sink for COS is evident in the vertical profile measurements from September 2004 and June 2005 (Fig. 4). Taken during day and night periods and in autumn and summer, these vertical profiles all showed decreasing COS mixing ratios from above the forest canopy to ground level. However, the pattern of COS decreases over the vertical gradient varied considerably reflecting different sampling times and wind conditions as well as spatial variability in the two rings. For example, on 26 September 2004 at 18:00 LT (Fig. 4a), R1 experienced a relatively consistent reduction in COS mixing ratios from $450 \mathrm{pptv}$ above the canopy $(20 \mathrm{~m})$ to $362 \mathrm{pptv}$ at $1 \mathrm{~m}$ above the ground revealing a strong canopy and ground level sink. In contrast, COS mixing ratios in $\mathrm{R} 2$ decreased from 413 pptv above the canopy to $370 \mathrm{pptv}$ at $10 \mathrm{~m}$ above ground before increasing to $394 \mathrm{pptv}$ again at ground level $(1 \mathrm{~m})$ suggesting a limited surface source at that location. Decreased COS mixing ratios occurred at ground level in all profiles in June 2005, including those in R2, indicating that conditions also favored a strong surface sink during the second field study (Fig. 4b, c, and d). Furthermore, the profile obtained at 00:30 LT on 6 June 2005 (Fig. 4c) revealed strong nighttime canopy sinks in both R1 and R2 with COS mixing ratios from 1 to $15 \mathrm{~m}$ above ground $(\mathrm{R} 1=309-359$ and $\mathrm{R} 2=316-412 \mathrm{pptv})$ well below levels observed above the canopy (406 and $417 \mathrm{pptv}$ at $20 \mathrm{~m}$ above ground in $\mathrm{R} 1$ and $\mathrm{R} 2$, respectively).

Previous studies of ambient COS mixing ratios in loblolly pine forests have indicated that COS uptake is highly variable. For example, vertical profiles obtained at the University of Georgia B. F. Grant research forest, a loblolly pine stand 
(a)

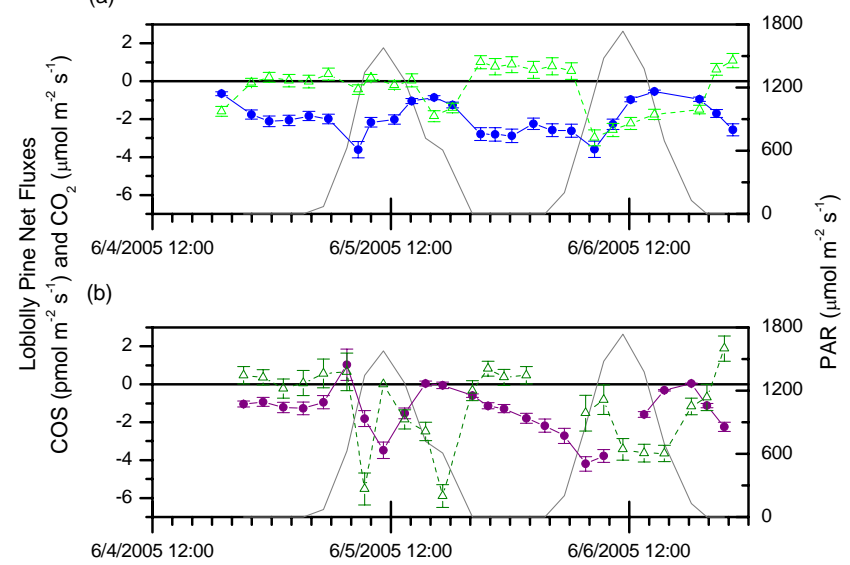

(c)

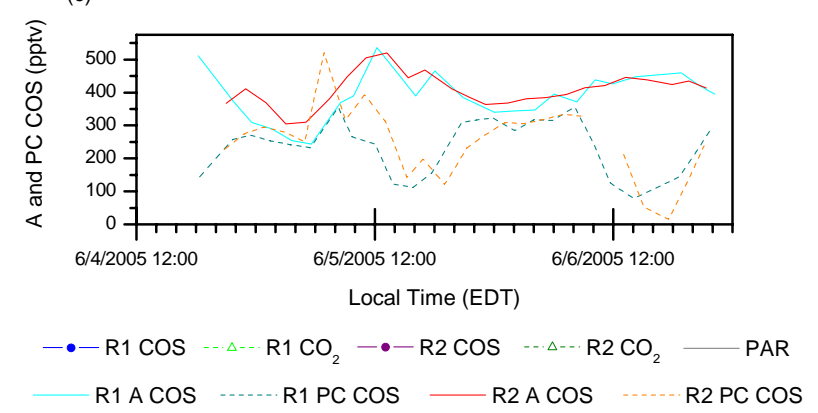

Fig. 5. Time series of branch enclosure measurements of net COS and $\mathrm{CO}_{2}$ flux for (a) R1 loblolly pine and (b) R2 loblolly pine. All fluxes are normalized to leaf area of the branch sampled $\left(\mathrm{m}^{2}\right)$. Measurements of photosynthetically active radiation (PAR) for the corresponding time periods are shown in $a$ and $b$ to help delineate day and night periods. Measurements of ambient (A) and post-catalyst (PC) COS mixing ratios entering the enclosure are given in (c). Error bars represent individual flux errors propagated from measurement uncertainties in $\mathrm{COS}, \mathrm{CO}_{2}$, leaf area, and inlet flow rate as described in Sect. 2.4.

located southeast of Atlanta, GA, suggested significant release of COS within the forest canopy (Berresheim and Vulcan, 1992). Ambient mixing ratios in the Georgia pine stand (500-900 pptv) were also significantly higher than those observed at DF reflecting COS sources that dominated over sinks in that region. At DF, direct measurements of COS consumption in branch enclosure sampling of the two dominant tree species in June 2005 (Sect. 3.3) provides strong evidence that these species were not a source of COS within the canopy. Instead, canopy increases in vertical mixing ratio profiles during this same time period implied that COS transport and turbulence within the canopy most likely impacted its daytime vertical distributions in June 2005.

\subsection{Vegetation flux measurements, June 2005}

Branch enclosure measurements performed in June 2005 show that both loblolly pine and sweetgum trees at DF were sinks for COS (Figs. 5 and 6). Negative fluxes, indicating

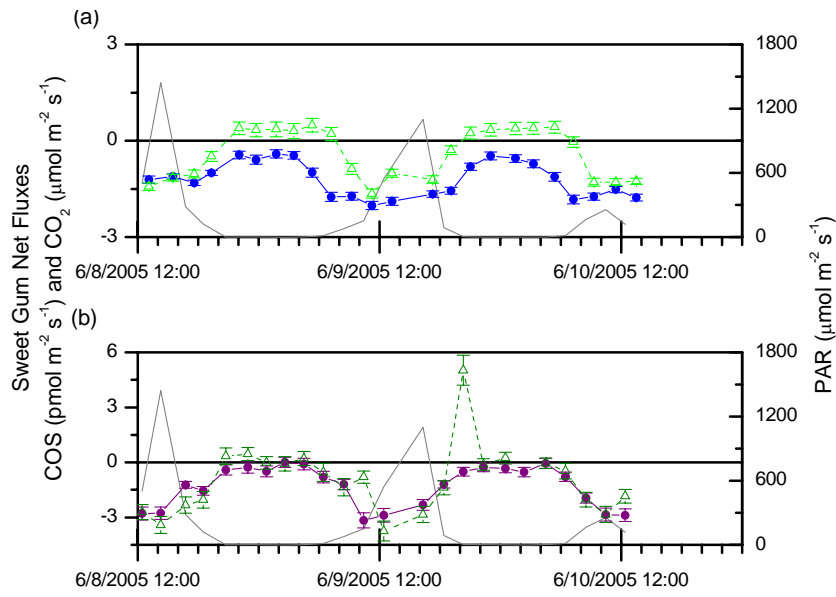

(c)

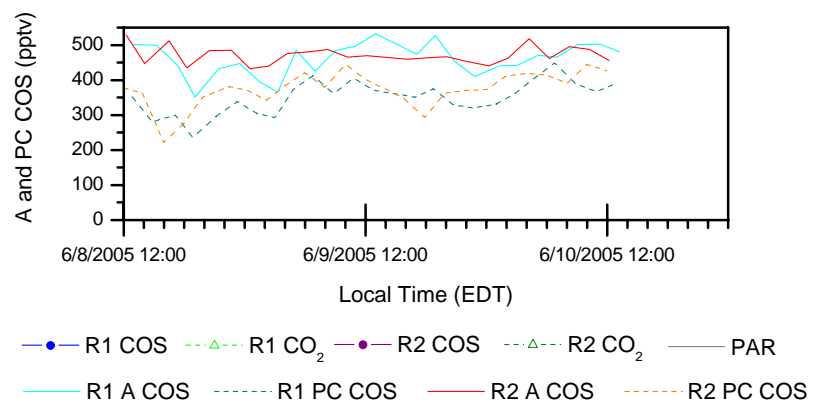

Fig. 6. Time series of branch enclosure measurements of net COS and $\mathrm{CO}_{2}$ flux for (a) R1 sweetgum and (b) R2 sweetgum. All fluxes are normalized to leaf area of the branch sampled $\left(\mathrm{m}^{2}\right)$. Measurements of photosynthetically active radiation (PAR) for the corresponding time periods are shown in a and $\mathrm{b}$ to help delineate day and night periods. Measurements of ambient (A) and post-catalyst (PC) COS mixing ratios entering the enclosure are given in (c). Error bars represent individual flux errors propagated from measurement uncertainties in $\mathrm{COS}, \mathrm{CO}_{2}$, leaf area, and inlet flow rate as described in Sect. 2.4.

uptake of COS from the atmosphere, dominated COS exchange for both species over $48 \mathrm{~h}$ sampling periods. The distinct diurnal patterns of COS fluxes observed for the two tree species reflect the multiple factors that can impact vegetative COS exchange such as ambient COS levels, environmental controls over stomatal conductance, and leaf photosynthetic capacity. The relationships between the COS vegetation fluxes measured at DF and these factors will be discussed in more depth in the following two sections.

\subsubsection{Post-catalyst COS levels}

For all trees sampled, net COS flux exhibited the strongest correlation with the post-catalyst (PC) COS levels flowing into the bag (Fig. 7). Similar strong correlations have been observed for crop plants (Kesselmeier and Merk, 1993) and deciduous trees in Northern China (Geng and Mu, 2006) indicating that the major factor controlling the rate of COS 

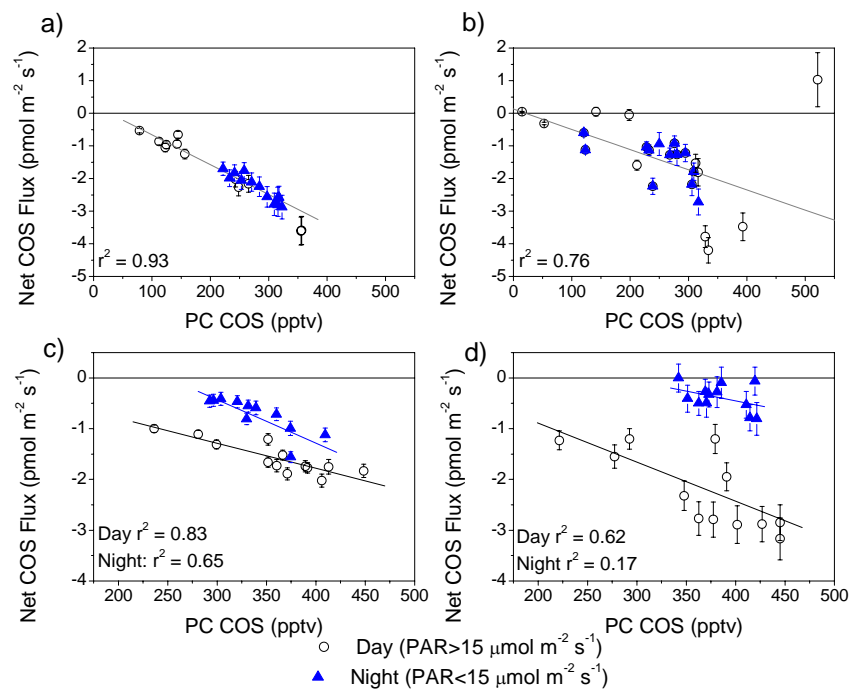

Fig. 7. The relationship between net COS flux and PC COS levels entering the enclosure for (a) R1 loblolly pine; (b) R2 loblolly pine; (c) R1 sweetgum; (d) R2 sweetgum. Lines are the linear regressions for (a) and (b) total data displayed; and (c) and (d) day and night data separately. Error bars represent individual flux errors propagated from measurement uncertainties in COS, leaf area, and inlet flow rate as described in Sect. 2.4.

uptake for many plants is the amount of ambient COS. The linear regressions for these relationships (Fig. 7) can be used to calculate compensation points, or the COS mixing ratios at which production and consumption processes balance each other and net flux equals zero. At DF, the daytime (PAR $>15 \mu \mathrm{mol} \mathrm{m}^{-2} \mathrm{~s}^{-1}$ ) compensation points were low (approximately 30, 20, 30, and 85 pptv for R1 and R2 loblolly pines and R1 and R2 sweetgums, respectively) compared to the ranges calculated for rapeseed and corn (90150 pptv; Kesselmeier and Merk, 1993) and selected Chinese deciduous trees (140-870 pptv; Geng and Mu, 2006). These low compensation points further emphasize the significance of the DF site as a net COS sink.

It should be noted that the unintentional removal of ambient COS by the palladium catalyst in the inlet airflow influenced the diurnal patterns and magnitudes of COS flux rates measured in the branch enclosures. For example, the significant afternoon depletion in PC COS mixing ratios responsible for the minimum uptake rates (least negative fluxes) observed for both R1 and R2 loblolly pines did not reflect ambient (A) COS conditions. As Fig. 5c indicates, ambient COS levels during loblolly pine measurements actually reached maximum values during the day following a diurnal pattern similar to that observed during non-hurricane periods in September 2004. The levels of PC COS were more consistent throughout the two day sampling period for the sweetgum trees although PC COS was depleted compared to ambient COS levels (Fig. 6c). The removal of COS from the inlet airflow suggests that the magnitude of COS uptake rates
Table 1. Mean $\mathrm{COS}$ and $\mathrm{CO}_{2}$ deposition velocities, $V_{\mathrm{d}}, \pm$ standard error $(n \geq 10)$, for Ring 1 and Ring 2 vegetation. $V_{\mathrm{d}}$ were calculated from measured flux rates normalized to leaf area (LA) of the branch enclosed divided by $\mathrm{PC} \mathrm{COS}$ and $\mathrm{CO}_{2}$ mixing ratios at the time of flux. Superscripts a, b, c, d, and e indicate significantly different means within each column $(p<0.05$, independent means t-test, SPSS v. 15.0.1.1).

\begin{tabular}{cccrr}
\hline \multirow{2}{*}{ Location } & Sink & $\begin{array}{c}\text { Measurement } \\
\text { Time }\end{array}$ & \multicolumn{2}{c}{$V_{\mathrm{d}}$ per LA $\left(\mathrm{cm} \mathrm{s}^{-1}\right)$} \\
\cline { 3 - 5 } R1 & Loblolly & Day & $2.0 \pm 0.1^{\mathrm{a}}$ & $0.9 \pm 0.2^{\mathrm{a}, \mathrm{b}}$ \\
& Pine & night & $2.0 \pm 0.1^{\mathrm{a}}$ & \\
& & & $1.1 \pm 0.1^{\mathrm{b}}$ & $0.6 \pm 0.1^{\mathrm{a}}$ \\
& Sweetgum & day & $0.5 \pm 0.1^{\mathrm{c}}$ & \\
& & night & & \\
$\mathrm{R} 2$ & Loblolly & day & $1.3 \pm 0.3^{\mathrm{a}, \mathrm{b}, \mathrm{c}, \mathrm{d}}$ & $0.9 \pm 0.2^{\mathrm{a}, \mathrm{b}}$ \\
& Pine & night & $1.4 \pm 0.1^{\mathrm{d}}$ & \\
& Sweetgum & day & $1.5 \pm 0.1^{\mathrm{d}}$ & $0.9 \pm 0.2^{\mathrm{b}}$ \\
& & night & $0.2 \pm 0.1^{\mathrm{e}}$ & \\
\hline
\end{tabular}

measured in both loblolly pine and sweetgum enclosures was lower than expected for the open canopy. As the strong negative correlations between PC COS levels and net COS uptake rates reveals (Fig. 7), higher ambient COS mixing ratios would result in higher uptake rates.

To provide a representative picture of loblolly pine and sweetgum COS uptake, independent of catalyst COS depletion, deposition velocities, $V_{\mathrm{d}}\left(\mathrm{cm} \mathrm{s}^{-1}\right)$, are provided in Table 1 and used in subsequent analyses. These are defined as the absolute value of the rate of flux divided by the corresponding PC COS levels at the time of measurement. For comparison, $V_{\mathrm{d}}$ values for $\mathrm{CO}_{2}$ are also shown in Table 1 . The loblolly pine and sweetgum $\operatorname{COS} V_{\mathrm{d}}$ measured at Duke Forest (daytime means $=2.0 \pm 0.1,1.3 \pm 0.3,1.1 \pm 0.1$, and $1.5 \pm 0.1 \mathrm{~cm} \mathrm{~s}^{-1}$ for R1 and R2 loblolly pine and R1 and R2 sweetgum, respectively) are consistent with the range of $\operatorname{COS} V_{\mathrm{d}}$ values obtained in other laboratory and field studies of deciduous and coniferous tree species $\left(0\right.$ to $18 \mathrm{~cm} \mathrm{~s}^{-1}$; Kesselmeier et al., 1993; Kuhn et al., 1999; Xu et al., 2002; Sandoval-Soto et al., 2005; Geng and Mu, 2006).

\subsubsection{Stomatal conductance and photosynthetic capacity}

The day and night relationships between COS net flux and PC COS levels displayed in Fig. 7 reveal distinct diurnal patterns of stomatal conductance for the loblolly pine and sweetgum trees. For example, similar relationships between day and night COS uptake rates and PC COS mixing ratios for R1 and R2 loblolly pines (Fig. 7a and b) resulted in relatively consistent day and night $\operatorname{COS} V_{\mathrm{d}}$ (Table 1; R1=2.0 \pm 0.1 and $2.0 \pm 0.1 \mathrm{~cm} \mathrm{~s}^{-1}, \mathrm{R} 2=1.2 \pm 0.4$ and $1.4 \pm 0.1 \mathrm{~cm} \mathrm{~s}^{-1}$ day and night means, respectively). Substantial overnight COS flux is surprising since vegetative uptake of this gas occurs through plant stomata which presumably are closed at night. 
Increasing evidence shows that a wide variety of plants, including several pine species, exhibit significant nighttime stomatal conductance (Caird et al., 2007). The COS uptake patterns observed in this study indicate that loblolly pine may fall into this category.

The absence of a strong relationship between PAR and $\operatorname{COS} V_{\mathrm{d}}$ for the loblolly pine trees is particularly significant when considering the nighttime depletion observed in the ambient canopy measurements from September 2004. Previous observations of nighttime depletion in ambient forest COS mixing ratios have been attributed primarily to soil sinks as vegetative uptake was largely limited to daylight hours (Kuhn et al., 1999; Steinbacher et al., 2004). However, comparable day and night $V_{\mathrm{d}}$ for the dominant tree species in the FACE rings at DF suggests vegetative uptake was a major nocturnal sink at this site, a possibility that will be explored in more depth in Sect. 3.5.

It is also interesting to note that COS uptake by loblolly pine trees did not have a significant correlation with $\mathrm{CO}_{2}$ uptake (Fig. 8). Several previous studies of vegetative COS consumption have indicated a strong relationship between photosynthetic $\mathrm{CO}_{2}$ assimilation and $\mathrm{COS}$ exchange (Kesselmeier and Merk, 1993; Kuhn et al., 1999; Geng and $\mathrm{Mu}, 2006$; Xu et al., 2002). However, Geng and Mu (2006) noted that strong correlations between $\mathrm{CO}_{2}$ and $\mathrm{COS}$ uptake in two Chinese deciduous trees were only observed during diurnal measurements made over one day. No significant linear correlations were observed when a larger data set of measurements was considered, which was attributed to the large variation in ambient $\mathrm{COS}$ mixing ratios (Geng and $\mathrm{Mu}$, 2006). Montzka et al. (2007) also noted the important influence of respiration and $\mathrm{CO}_{2}$ loss during photosynthesis on vegetative $\mathrm{CO}_{2}$ exchange, processes which are not mirrored in vegetative $\mathrm{COS}$ exchange. It is possible that any daytime relationship between $\mathrm{COS}$ uptake and $\mathrm{CO}_{2}$ assimilation for the loblolly pines was obscured by the significant influence of the wide range of $\mathrm{PC} \mathrm{COS} \mathrm{mixing} \mathrm{ratios} \mathrm{on} \mathrm{net} \mathrm{COS} \mathrm{flux}$ in combination with loblolly pine respiration and $\mathrm{CO}_{2}$ loss. However, the large nighttime $\operatorname{COS} V_{\mathrm{d}}$ measured in this study shows significant COS consumption occurred independently of $\mathrm{CO}_{2}$ assimilation in the loblolly pines.

Interestingly, the mean nighttime R2 loblolly pine COS $V_{\mathrm{d}}$ was significantly lower than the day and night means for the R1 loblolly pine (Table 1). Long-term photosynthetic acclimation to elevated $\mathrm{CO}_{2}$ in loblolly pines at DF has been linked to reduced activity of the carboxylation enzyme Rubisco, involved in the light-independent reactions of the Calvin cycle, in one-year old needles (Rogers and Ellsworth, 2002). As Rubisco can enhance COS uptake by consuming the $\mathrm{CO}_{2}$ or $\mathrm{HCO}_{3}^{-}$produced by COS hydrolysis (ProtoschillKrebs and Kesselmeier, 1992), any reduction in its activity is likely to affect COS uptake rates. As a result, reduced COS $V_{\mathrm{d}}$ for the R2 loblolly pine could reflect photosynthetic acclimation to long-term elevated $\mathrm{CO}_{2}$ exposure (Rogers and Ellsworth, 2002). (a)

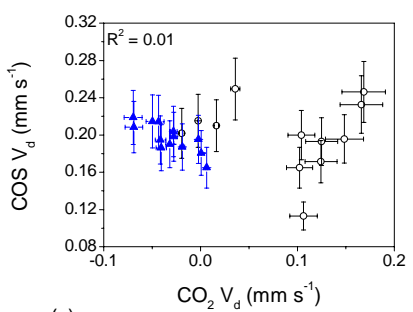

(c)

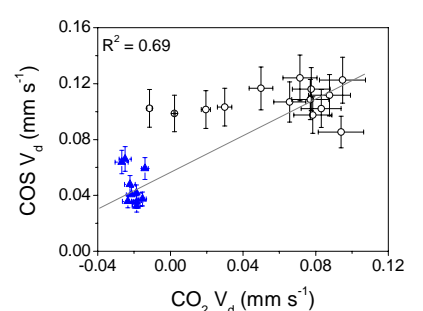

(d)

(b)
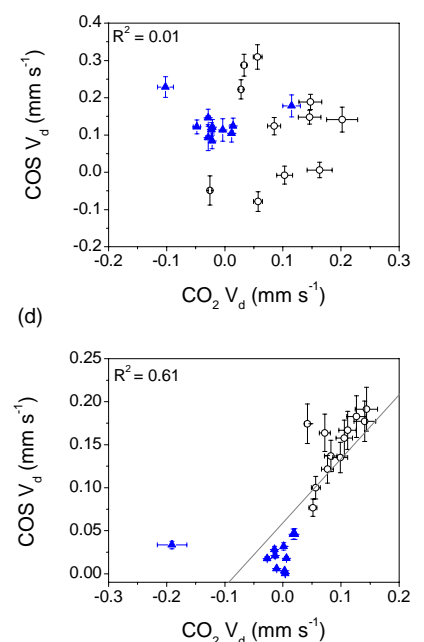

Day $\left(\right.$ PAR $\left.>15 \mu \mathrm{mol} \mathrm{m} \mathrm{m}^{-2} \mathrm{~s}^{-1}\right)$

- Night $\left(\right.$ PAR $<15 \mu \mathrm{mol} \mathrm{m} \mathrm{m}^{-2} \mathrm{~s}^{-1}$

Fig. 8. The relationship between $\mathrm{COS}$ and $\mathrm{CO}_{2} V_{\mathrm{d}}$ for (a) $\mathrm{R} 1$ loblolly pine; (b) R2 loblolly pine; (c) R1 sweetgum; (d) R2 sweetgum. Negative values indicate emission to the atmosphere. Lines shown in (c) and (d) are the linear regressions for total data displayed. Error bars represent individual $V_{\mathrm{d}}$ errors propagated from measurement uncertainties in $\mathrm{COS}, \mathrm{CO}_{2}$, leaf area, and inlet flow rate as described in Sect. 2.4.

In contrast to the loblolly pines, the clear separation between day and nighttime flux relationships with PC COS for the deciduous sweetgum trees does reflect substantial stomatal closure at night (Fig. 7c and d). The significantly different day and night mean sweetgum $\operatorname{COS} V_{\mathrm{d}}$ values (Table 1 ; $\mathrm{R} 1=1.1 \pm 0.1$ and $0.5 \pm 0.1, \mathrm{R} 2=1.5 \pm 0.1$ and $0.2 \pm 0.1 \mathrm{~cm} \mathrm{~s}^{-1}$ day and night means, respectively) are consistent with field measurements of live oak (Quercus agrifolia), a deciduous macrophyte in a California oak forest (Kuhn et al., 1999), and a variety of deciduous trees in Northern China (Geng and $\mathrm{Mu}, 2006$ ), all of which showed strong relationships between net COS uptake and light. As a result, the R1 and R2 sweetgum $\operatorname{COS} V_{\mathrm{d}}$ values were significantly correlated to changes in PAR (R1 $r^{2}=0.23, p=0.02$; R2 $r^{2}=0.48, p<0.001$ ), enclosure temperature (R1 $r^{2}=0.54, p<0.001 ; \mathrm{R} 2 r^{2}=0.74$, $p<0.001)$, and $\mathrm{CO}_{2} V_{\mathrm{d}}\left(\mathrm{R} 1 r^{2}=0.65, p<0.001 ; \mathrm{R} 2 r^{2}=0.61\right.$, $p<0.001$ ).

Sweetgum trees exposed to elevated $\mathrm{CO}_{2}$, like those in $\mathrm{R} 2$, have shown significant reductions in stomatal conductance which should reduce COS uptake (Herrick et al., 2004). Instead, significantly higher daytime $\mathrm{COS}$ and $\mathrm{CO}_{2} \quad V_{\mathrm{d}}$ for sweetgum in $\mathrm{R} 2$ compared to R1 (Table 1; R1=1.1 $\pm 0.1 \mathrm{~cm} \mathrm{~s}^{-1}$ and $0.6 \pm 0.1 \mathrm{~cm} \mathrm{~s}^{-1}$, $\mathrm{R} 2=1.5 \pm 0.1 \mathrm{~cm} \mathrm{~s}^{-1}$ and $0.9 \pm 0.2 \mathrm{~cm} \mathrm{~s}^{-1}$ for $\operatorname{COS}$ and $\mathrm{CO}_{2}$, respectively) suggests that the sweetgum branch sampled in R2 had a higher photosynthetic capacity than that in $\mathrm{R} 1$. These differences in $\mathrm{COS}$ and $\mathrm{CO}_{2} V_{\mathrm{d}}$ most likely 
(a)

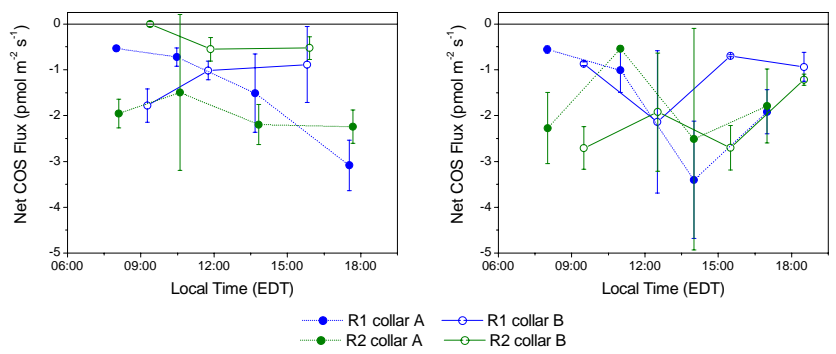

Fig. 9. Chamber measurements of soil COS flux on (a) 9 June 2005 and (b) 20 September 2005. All fluxes are normalized to ground area $\left(\mathrm{m}^{2}\right)$. Error bars represent individual flux errors propagated from the standard error of regression analyses, and measurement uncertainties in COS, collar area, chamber volume, and inlet flow rate as described in Sect. 2.5.

reflect variations in the canopy position of the two sweetgum branches sampled as the branch in R1 was more sheltered (less open sunlight) than the R2 branch. Observations of sweetgum sun and shade leaves at DF indicates that the photosynthetic capacity and stomatal conductance of sun leaves at the top of the canopy was significantly higher than that of shade leaves in the understory (Herrick and Thomas, 2001; Herrick et al., 2004). Similar effects of canopy position on $\mathrm{COS}$ consumption rates have also been noted for a tropical rainforest tree species in Cameroon where COS deposition at the top of the canopy was nearly 4 times that measured for the same species growing at ground level (Kesselmeier et al., 1993).

It should be noted that the limited sample size in this study may have prevented direct observations of the effect of $\mathrm{CO}_{2}$ enrichment on COS uptake. As noted previously, long-term $\mathrm{CO}_{2}$ enrichment does have significant effects on both photosynthetic capacity and stomatal conductance in loblolly pines and sweetgums (Rogers and Ellsworth, 2002; Herrick et al., 2004). Because stomatal conductance and photosynthetic capacity variability resulting from environmental and spatial heterogeneity were major factors impacting COS uptake rates in this study, it is probable that $\mathrm{CO}_{2}$ effects on these characteristics will also have an impact on vegetative COS uptake within the two environments. This potential influence on the net ecosystem flux estimates for the two rings will be considered more in Sect. 3.5.

\subsection{Soil flux measurements, June and September 2005}

Soil was also a net sink for COS at DF (Table 2, Fig. 9). The range of net fluxes observed in the soil static chamber measurements (R1: -3 to $-0.53 \mathrm{pmol} \mathrm{m}^{-2} \mathrm{~s}^{-1}$; R2: -2.7 to $0 \mathrm{pmol} \mathrm{m}^{-2} \mathrm{~s}^{-1}$ ) were comparable to other field studies in a spruce forest in Germany $\left(-1.38\right.$ to $-0.23 \mathrm{pmol} \mathrm{m}^{-2} \mathrm{~s}^{-1}$; Steinbacher et al., 2004), a California oak forest $(-13.3$ to $-8.8 \mathrm{pmol} \mathrm{m}^{-2} \mathrm{~s}^{-1}$; Kuhn et al., 1999), and three types of Chinese subtropical forests ( -11.82 to $-1.22 \mathrm{pmol} \mathrm{m}^{-2} \mathrm{~s}^{-1}$;
Yi et al., 2007). There were no significant differences between R1 and R2 mean net fluxes indicating that $\mathrm{CO}_{2}$ enrichment had little effect on soil COS consumption.

Only one significant difference was observed in the soil fluxes measured at DF. This occurred between R2 collars $\mathrm{A}$ and $\mathrm{B}$ on 9 June 2005 (Fig. 9a; mean flux $=-2.0 \pm 0.2$ and $-0.4 \pm 0.2 \mathrm{pmol} \mathrm{m}^{-2} \mathrm{~s}^{-1}$ for R2 collar $\mathrm{A}$ and $\mathrm{B}$, respectively). This was not a consistent difference as the mean R2 collar fluxes were more comparable on 20 September 2005 (Fig. 9b; Collar $\mathrm{A}=-1.8 \pm 0.4 \mathrm{pmol} \mathrm{m}^{-2} \mathrm{~s}^{-1}$, Collar $\mathrm{B}=-2.1 \pm 0.4 \mathrm{pmol} \mathrm{m}^{-2} \mathrm{~s}^{-1}$ ). Laboratory studies indicate that soil temperature, moisture content, porosity, and ambient levels of COS all can affect COS consumption in soils (Kesselmeier et al., 1999; Van Diest and Kesselmeier, 2008). While there were no significant differences in soil temperature or ambient COS levels between the two collars on 9 June, the variability in measured fluxes could reflect a spatial difference in soil moisture content or porosity in R2. Spatial variability in soil moisture and gas transport conditions from differences in topography and/or vegetation was not captured in the soil moisture content measurements, which were averages from four TDR instruments located in each ring.

The only significant correlation observed for the DF soil fluxes was between deposition velocities, $V_{\mathrm{d}}$, and soil surface temperature (Fig. 10, $r^{2}=0.32, p=0.001$ ). The proportion of $V_{\mathrm{d}}$ variability attributable to the temperature relationship, indicated by the coefficient of determination $\left(r^{2}\right)$, was small and suggests that there were other major unidentified factors affecting the COS uptake flux at DF. Other field studies of forest soils have also shown widely variable responses to soil moisture and temperature. For example, an in-situ study of German spruce forest soil indicated optimum net COS fluxes at lower temperatures and higher soil moisture contents than observed in laboratory studies (Steinbacher et al., 2004). Furthermore, a soil uptake study conducted in three Chinese subtropical forest types indicated the strongest individual correlations for net COS soil uptake with soil respiration and ambient levels of COS, rather than with soil moisture or temperature (Yi et al., 2007).

Such highly variable relationships with COS net flux reflect both the complexity of interactions in natural environments as well as the potential effect of different soil types and microbial communities on COS gas exchange. For example, differences in COS deposition velocities observed in laboratory studies of boreal soils from several different geographic locations could be accounted for by differences in soil porosity (Van Diest and Kesselmeier, 2008). Similarly, differences in the temperature range of maximum COS deposition velocities from laboratory incubations of boreal and temperate soil samples suggest variable adaptations of the microbial communities within different climate zones (Van Diest and Kesselmeier, 2008). Further studies of COS uptake in a variety of soils in both laboratory and field settings are clearly needed to more fully characterize this COS sink. 
Table 2. Means \pm standard error $(n \geq 7)$ for the soil static chamber measurements made in June and September 2005 . Mean fluxes and deposition velocities, $V_{\mathrm{d}}$, are normalized to ground area (GA). Superscripts a, b, c, and d indicate significantly different means within each column $(p<0.05$, independent means t-test, SPSS v. 15.0.1.1).

\begin{tabular}{|c|c|c|c|c|c|c|c|c|c|}
\hline Month & Ring & $\begin{array}{c}\text { Net COS flux } \\
\left(\mathrm{pmol} \mathrm{m}^{-2} \mathrm{~s}^{-1}\right)\end{array}$ & $\begin{array}{c}\text { Ambient } \\
\text { COS } \\
\text { (pptv) }\end{array}$ & $\begin{array}{l}\operatorname{COS} V_{\mathrm{d}} \\
\text { per GA } \\
\left(\mathrm{cms}^{-1}\right)\end{array}$ & $\begin{array}{l}\text { Air Temp } \\
\quad\left({ }^{\circ} \mathrm{C}\right)\end{array}$ & $\begin{array}{c}\text { Surface Temp } \\
\left({ }^{\circ} \mathrm{C}\right)\end{array}$ & $\begin{array}{c}5 \mathrm{~cm} \\
\text { Depth Temp } \\
\left({ }^{\circ} \mathrm{C}\right)\end{array}$ & $\begin{array}{c}10 \mathrm{~cm} \\
\text { Depth Temp } \\
\left({ }^{\circ} \mathrm{C}\right)\end{array}$ & $\begin{array}{l}\text { Volumetric } \\
\text { Soil Moisture } \\
\left(\mathrm{m}^{3} \mathrm{~m}^{-3}\right)\end{array}$ \\
\hline \multirow[t]{2}{*}{ June } & 1 & $-1.4 \pm 0.3^{\mathrm{a}}$ & $520 \pm 30^{\mathrm{a}}$ & $0.6 \pm 0.1^{\mathrm{a}}$ & $24.3 \pm 0.6^{\mathrm{a}}$ & $22.8 \pm 0.4^{\mathrm{a}}$ & $20.1 \pm 0.2^{\mathrm{a}}$ & $19.7+0.2^{\mathrm{a}}$ & $0.296 \pm 0.007^{\mathrm{a}}$ \\
\hline & 2 & $-1.3 \pm 0.3^{\mathrm{a}}$ & $500 \pm 30^{\mathrm{a}}$ & $0.6 \pm 0.2^{\mathrm{a}}$ & $24.6 \pm 0.6^{\mathrm{a}}$ & $22.5 \pm 0.5^{\mathrm{a}}$ & $20.5 \pm 0.2^{\mathrm{a}}$ & $19.8+0.2^{\mathrm{a}}$ & $0.384 \pm 0.009^{b}$ \\
\hline \multirow[t]{2}{*}{ September } & 1 & $-1.4 \pm 0.3^{\mathrm{a}}$ & $340 \pm 10^{\mathrm{b}}$ & $1.0 \pm 0.2^{\mathrm{a}, \mathrm{b}}$ & $27.7 \pm 0.7^{b}$ & $26.5 \pm 0.8^{b}$ & $22.7 \pm 0.2^{b}$ & $22.3+0.1^{\mathrm{b}}$ & $0.205 \pm 0.001^{\mathrm{c}}$ \\
\hline & 2 & $-2.0 \pm 0.3^{\mathrm{a}}$ & $352 \pm 6^{\mathrm{b}}$ & $1.4 \pm 0.2^{\mathrm{b}}$ & $27.3 \pm 0.8^{\mathrm{b}}$ & $27.2 \pm 0.8^{b}$ & $22.6 \pm 0.1^{b}$ & $22.3+0.2^{\mathrm{b}}$ & $0.233 \pm 0.001^{\mathrm{d}}$ \\
\hline
\end{tabular}

(a)

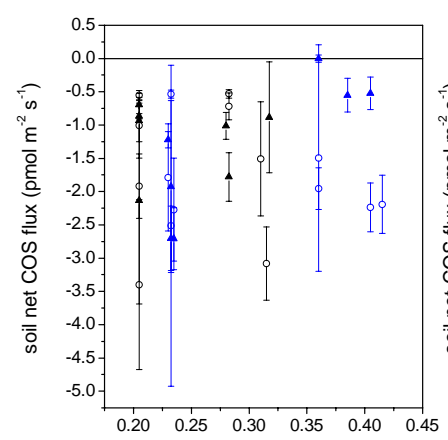

volumetric soil moisture content $\left(\mathrm{m}^{3} \mathrm{~m}^{-3}\right)$

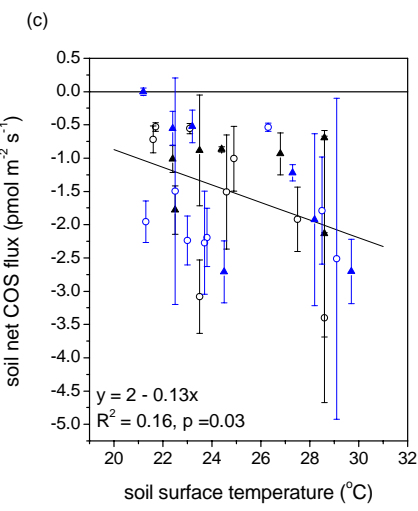

(b)

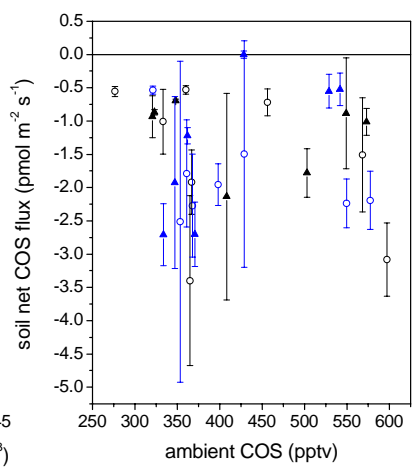

(d)

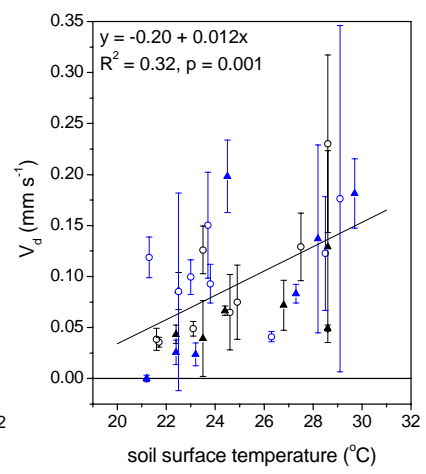

- R1 collar A

- R1 collar B

- R2 collar A

- R2 collar B

Fig. 10. Soil net COS flux versus (a) volumetric soil moisture; (b) ambient COS mixing ratios; and (c) soil surface temperature. (d) displays the relationship between soil COS flux normalized to ambient COS mixing ratios, $V_{\mathrm{d}}$, versus surface temperature. Error bars represent individual flux errors propagated from the standard error of regression analyses, and measurement uncertainties in COS, collar area, chamber volume, and inlet flow rate as described in Sect. 2.5.

\subsection{Estimates of net ecosystem COS flux, September 2004 and June 2005}

The net ecosystem flux results, NF, calculated using Eq. (5) for 15-16 September 2004 and 4-5 June 2005 represent the best estimate of ecosystem level nighttime exchange processes at DF (Fig. 11). It should be noted that the limited number of low wind speed nights and the lack of ML height measurements contributed to the large uncertainty for these calculations. However as a first approximation, the NF estimates allow a valuable comparison between the individual vegetation and soil sinks measured and the net COS uptake rates observed at DF.

The NF estimates were generally consistent with the combined vegetation and soil flux estimates for both nights (Fig. 11). It should be noted that the vegetation and soil fluxes for 15 September $2004(-19 \pm 6$ and $-13 \pm 4 \mathrm{pmol} \mathrm{m}^{-2} \mathrm{~s}^{-1}$ combined for R1 and R2, respectively) were calculated using deposition velocities measured at other times during the year and the slightly higher mean $\mathrm{NF}$ estimates for that night $\left(-30 \pm 20 \mathrm{pmol} \mathrm{m}^{-2} \mathrm{~s}^{-1}\right.$ for both $\mathrm{R} 1$ and R2) could reflect the effect of seasonal differences in temperature and/or soil moisture on stomatal conductance and COS uptake. In contrast, the June $2005 \mathrm{NF}$ estimates $\left(-20 \pm 10\right.$ and $-10 \pm 10 \mathrm{pmol} \mathrm{m}^{-2} \mathrm{~s}^{-1}$ in $\mathrm{R} 1$ and $\mathrm{R} 2$, respectively) and vegetation and soil fluxes $(-22 \pm 8$ and $-17 \pm 6 \mathrm{pmol} \mathrm{m}^{-2} \mathrm{~s}^{-1}$ combined in R1 and R2, respectively) were all calculated from measurements made within the same week. This agreement between the COS flux calculations indicates that the NF estimates and enclosure measurements reasonably represent ecosystem exchange processes.

It is worth noting that NF estimates of R2 ecosystem COS uptake in June $2005\left(-10 \pm 10 \mathrm{pmol} \mathrm{m}^{-2} \mathrm{~s}^{-1}\right)$ were approximately half the NF estimates in R1 $\left(-20 \pm 10 \mathrm{pmol} \mathrm{m}^{-2} \mathrm{~s}^{-1}\right.$; Fig. 11). Because of the large uncertainties associated with the NF calculations, these differences cannot be considered significant. However, the observations of reduced stomatal conductance in sweetgum trees and photosynthetic downregulation in loblolly pines associated with long-term $\mathrm{CO}_{2}$ enrichment at DF (Rogers and Ellsworth, 2002; Herrick et al., 2004) suggests that lower ecosystem COS uptake rates in 


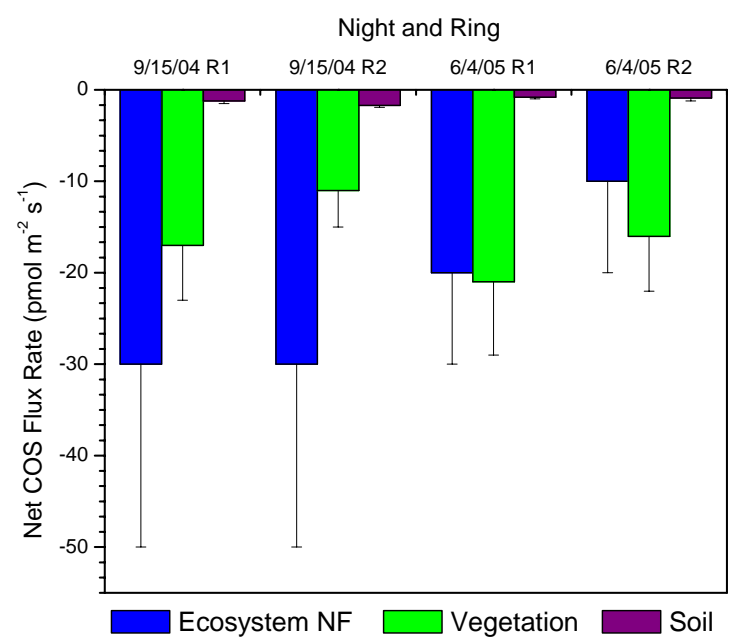

Fig. 11. Comparison of nighttime ecosystem uptake rate (NF) estimates with vegetation and soil uptake rate estimates on 1516 September 2004 and 4-5 June 2005. Error bars for ecosystem NF estimates were propagated from the standard error of the mean NF rates calculated for each night $(n \geq 4)$ and the estimated uncertainty in mixing layer height $(60 \%)$ as described in Sect. 2.6. Error bars for the vegetation uptake rate estimates were propagated from the standard error of the mean night vegetation $V_{\mathrm{d}}$ values from June $2005(n \geq 23)$ and the mean ambient COS values for the nights represented ( $n \geq 5)$. Error bars for the soil uptake rate estimates were propagated from the standard error of the mean nighttime soil $V_{\mathrm{d}}$ values from September $2005(n=8)$ and June $2005(n=7)$ and the mean ambient COS values for the nights represented $(n \geq 5)$.

$\mathrm{R} 2$ could reflect the effects of $\mathrm{CO}_{2}$ enrichment. A reduction in the vegetative $\mathrm{COS}$ uptake capacity due to $\mathrm{CO}_{2}$ enrichment effects would also explain why higher overnight canopy COS levels in R2 on 4-5 June 2005 (R1=290 20 pptv, $\mathrm{R} 2=350 \pm 20 \mathrm{pptv}$ ) did not result in greater R2 net ecosystem COS uptake rates. However, similar NF estimates in R1 and R2 in September 2004 suggest that the magnitude of this effect was not consistent throughout the year and may depend upon the variability of other environmental controls over stomatal conductance and photosynthetic capacity such as temperature, soil moisture, or dominant leaf age.

Compared to other forest studies, the estimates of nighttime COS uptake at DF were large. Similar NF estimates of net ecosystem flux in a California oak forest $\left(-2.4 \mathrm{pmol} \mathrm{m}^{-2} \mathrm{~s}^{-1}\right.$; Kuhn et al., 1999) were an order of magnitude smaller than those calculated for DF, while nighttime COS fluxes measured using relaxed eddy accumulation (REA) methods in a German spruce forest were generally positive indicating emission (Xu et al., 2002). Soil was the only observed COS nighttime sink in both of those studies. In contrast, the significant overnight deposition rates observed for loblolly pines at DF strongly influenced nighttime COS fluxes. Overall, COS uptake by vegetation comprised 37 to $100 \%$ of observed NF net ecosystem flux estimates (Fig. 11).

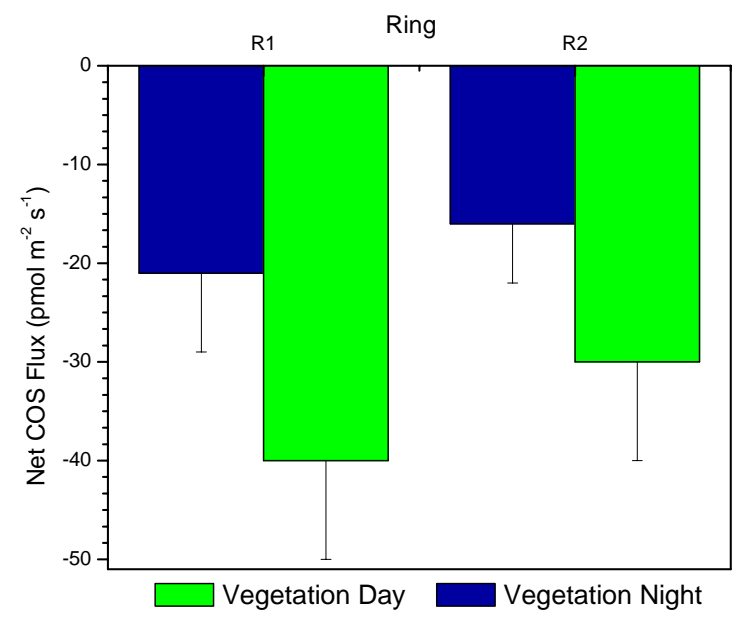

Fig. 12. Comparison of day and night vegetation uptake rates estimated for 4-5 June 2005. Error bars for the vegetation uptake rate estimates were propagated from the standard error of the mean day $(n \geq 24)$ and night $(n \geq 23)$ vegetation $V_{\mathrm{d}}$ values from June 2005 and the mean ambient COS values $(n \geq 5)$ for 4-5 June 2005 as described in Sect. 2.6.

For comparison to nighttime estimates of vegetative $\mathrm{COS}$ flux rates on 4-5 June 2005, estimates of the corresponding daytime rates were also calculated using Eq. (6) and mean daytime $V_{\mathrm{d} \text {,veg }}$ and ambient $\operatorname{COS}$ mixing ratios for 4 June (Fig. 12). Nighttime vegetative COS uptake rates at DF were $50 \%$ of daytime values (day: $-40 \pm 10$ and $-30 \pm 10$ and night: $-21 \pm 8$ and $-16 \pm 6 \mathrm{pmol} \mathrm{m}^{-2} \mathrm{~s}^{-1}$ in R1 and R2, respectively). This suggests that as much as $33 \%$ of the daily COS vegetative consumption at DF occurred independently of $\mathrm{CO}_{2}$ assimilation. These results have important implications for global estimates of the vegetative COS sink strength. Sandoval-Soto et al. (2005) and Montzka et al. (2007) have pointed out that estimates of the global COS vegetative sink made by scaling net primary productivity $\left(\mathrm{NPP}=\mathrm{CO}_{2}\right.$ photosynthetic consumption - respiration) by the ratio of the mean atmospheric mixing ratios for $\mathrm{COS}$ and $\mathrm{CO}_{2}$ should be reconsidered to account for the larger vegetative $V_{\mathrm{d}}$ of COS compared to $\mathrm{CO}_{2}$. In support of this, recent model results of COS atmospheric concentrations based on gross primary productivity $\left(\mathrm{GPP}=\mathrm{CO}_{2}\right.$ photosynthetic consumption only) and leaf scale relative uptake rates measured in chamber experiments were in much closer agreement with observations of vertical COS depletion in the atmospheric boundary layer of the continental United States (Campbell et al., 2008). However, observations of significant nighttime stomatal conductance in loblolly pine and a wide variety of other plant species (Caird et al., 2007) suggests GPP based models may still underestimate the global COS vegetative sink strength. The significant nighttime COS flux observed in the loblolly pine stand indicates COS vegetative uptake that occurs independently of $\mathrm{CO}_{2}$ photosynthetic consumption can also be significant and should be considered in global vegetative sink strength estimates. 


\section{Conclusions}

Vegetation, soil, and canopy COS measurements in 2004 and 2005 all indicate that the Duke Forest FACE site was generally a net sink for COS. Vegetative uptake patterns for the loblolly pine and sweetgum trees sampled were significantly different in R1 and R2, but these differences most likely reflected environmental and canopy spatial effects on the stomatal conductance and photosynthetic capacity of the branches measured rather than $\mathrm{CO}_{2}$ enrichment effects. However, observations of lower nighttime net ecosystem COS uptake in R2 compared to R1 in June 2005 does suggest that the total canopy vegetative COS uptake capacity was reduced with elevated $\mathrm{CO}_{2}$ exposure. This effect was not observed in September 2004 and may have depended on the variability of other environmental controls over vegetation stomatal conductance and photosynthetic capacity. Soil consumption, which was a minor component of net ecosystem COS uptake in both ambient and enhanced $\mathrm{CO}_{2}$ rings, was not significantly different between R1 and R2.

Nighttime minimums in canopy COS mixing ratios reflected significant nighttime COS consumption by loblolly pines in both ambient and enhanced $\mathrm{CO}_{2}$ rings. Nighttime vegetation uptake rates were approximately $50 \%$ of daytime vegetation rates. These observations of substantial vegetative $\mathrm{COS}$ consumption that occurred independently of $\mathrm{CO}_{2}$ assimilation suggest that current estimates of the global vegetative COS sink, which assume that COS and $\mathrm{CO}_{2}$ assimilation occur simultaneously, may need to be re-evaluated.

Acknowledgements. Financial support for this work was provided through the US EPA-STAR program under grant \#RD-8314540 and the Office of Oceanic and Atmospheric Research of the National Oceanic and Atmospheric Administration under AIRMAP grant \#NA06OAR4600189 to UNH. Research at the Duke FACE site was also supported by the Office of Science (BER), US Department of Energy, Grant No. DE-FG02-95ER62083. A special thanks to T. Finnigan-Allen, A. Csakai, M. Hunter and P. Beckman at UNH as well as the staff at the Duke FACE site.

Edited by: J. Kesselmeier

\section{References}

Aneja, V. P., Overton, J. H., Cupitt, L. T., Durham, J. L., and Wilson, W. E.: Carbon disulphide and carbonyl sulphide from biogenic sources and their contributions to the global sulphur cycle, Nature, 282, 493-496, 1979.

Barnes, I., Becker, K. H., and Patroescu, I.: The tropospheric oxidation of dimethyl sulfide: A new source of carbonyl sulfide, Geophys. Res. Lett., 21, 2389-2392, 1994.

Berresheim, H. and Vulcan, V. D.: Vertical distributions of COS, $\mathrm{CS}_{2}$, DMS and other sulfur compounds in a loblolly pine forest, Atmos. Environ., 26A, 2031-2036, 1992.
Bonan, G. B.: Forests and climate change: Forcings, feedbacks, and the climate benefits of forests, Science, 320, 1444, doi:10.1126/science.1155121, 2008.

Brown, K. A. and Bell, J. N. B.: Vegetation - the missing sink in the global cycle of carbonyl sulphide (COS), Atmos. Environ. 20, 537-540, 1986.

Caird, M. A., Richards, J. H., and Donovan, L. A.: Nighttime stomatal conductance and transpiration in $\mathrm{C}_{3}$ and $\mathrm{C}_{4}$ plants, Plant Physiol., 143, 4-10, 2007.

Campbell, J. E., Carmichael, G. R., Chai, T., Mena-Carrasco, M., Tang, Y., Blake, D. R., Blake, N. J., Vey, S. A., Collatz, G. J., Baker, I., Berry, J. A., Montzka, S. A., Sweeney, C., Schnoor, J. L., and Stanier, C. O.: Photosynthetic control of atmospheric carbonyl sulfide during the growing season, Science, 322, 10851088, 2008.

Castro, M. S. and Galloway, J. N.: A comparison of sulfur-free and ambient air enclosure techniques for measuring the exchange of reduced sulfur gases between soils and the atmosphere, J. Geophys. Res., 96, 15427-15437, 1991.

Chin, M. and Davis, D. D.: Global sources and sinks of OCS and $\mathrm{CS}_{2}$ and their distribution, Global Biogeochem. Cy., 7, 321-337, 1993.

Chin, M. and Davis, D. D.: A reanalysis of carbonyl sulfide as a source of stratospheric background sulfur aerosol, J. Geophys Res., 100, 8993-9005, 1995.

deMello, W. Z. and Hines, M. E.: Application of static and dynamic enclosures for determining dimethyl sulfide and carbonyl sulfide exchange in Sphagnum peatlands: Implications for the magnitude and direction of flux, J. Geophys. Res., 99, 14601-14607, 1994.

Elliot, S., Lu, E., and Rowland, F. S.: Rates and mechanisms for the hydrolysis of carbonyl sulfide in natural waters, Environ. Sci. Technol., 23, 458-461, 1989.

FACTS-1 LAI-2000 Leaf Area Index measurements: http://face. env.duke.edu/products.cfm, last access: 15 June 2007, 2006a.

FACTS-1 Soil moisture measurements: http://face.env.duke.edu/ products.cfm, last access: 15 June 2007, 2006 b.

Galbally, I.: Some measurements of ozone variation and destruction in the atmospheric surface layer, Nature, 218, 456-457, 1968.

Geng, C. and $\mathrm{Mu}$, Y.: Carbonyl sulfide and dimethyl sulfide exchange between trees and the atmosphere, Atmos. Environ., 40, 1373-1383, 2006.

Goldan, P. D., Fall, R., Kuster, W. C., and Fehsenfeld, F. C.: Uptake of COS by growing vegetation: A major tropospheric sink, J. Geophys. Res., 93, 14186-14192, 1988.

Greenwood, D. R., Scarr, M. J., and Christophel, D. C.: Leaf stomatal frequency in the Australian tropical rainforest tree Neolitsea dealbata (Lauraceae) as a proxy measure of atmospheric $p \mathrm{CO}(2)$, Palaeogeogr. Palaeocl., 196, 375-393, 2003.

Güsten, H., Heinrich, G., and Sprung, D.: Nocturnal depletion of ozone in the Upper Rhine Valley, Atmos. Environ, 32, 11951202, 1998.

Hastie, D. R., Shepson, P. B., Sharma, S., and Schiff, H. I.: The influence of the nocturnal boundary layer on secondary trace species in the atmosphere at Dorset, Ontario, Atmos. Environ. A-Gen., 27, 533-541, 1993. 
Herrick, J. D. and Thomas, R. B.: No photosynthetic downregulation in sweetgum trees (Liquidambar styraciflua) after three years of $\mathrm{CO}_{2}$ enrichment at the Duke Forest FACE experiment, Plant Cell Environ., 24, 53-64, 2001.

Herrick, J. D., Maherali, H., and Thomas, R. B.: Reduced stomatal conductance in sweetgum (Liquidambar styraciflua) sustained over long-term $\mathrm{CO}_{2}$ enrichment, New Phytol., 162, 387-396, 2004.

Hungate, B. A., Reichstein, M., Dijkstra, P., Johnson, D., Hymus, G., Tenhunen, J. D., Hinkle, C. R., and Drake, B. G.: Evapotranspiration and soil water content in a scrub-oak woodland under carbon dioxide enrichment, Glob. Change Biol., 8, 289-298, 2002.

Kammann, C., Grunhage, L., Gruters, U., Janze, S., and Jager, H. J.: Response of aboveground grassland biomass and soil moisture to moderate long-term $\mathrm{CO}_{2}$ enrichment, Basic Appl. Ecol., 6, 351$365,2005$.

Kesselmeier, J., Meixner, F. X., Hofmann, U., Ajavon, A.-L., Leimbach, S., and Andreae, M. O.: Reduced sulfur compound exchange between the atmosphere and tropical tree species in southern Cameroon, Biogeochemistry, 23, 23-45, 1993.

Kesselmeier, J. and Merk, L.: Exchange of carbonyl sulfide (COS) between agricultural plants and the atmosphere: Studies on the deposition of COS to peas, corn and rapeseed, Biogeochemistry, 23, 47-59, 1993.

Kesselmeier, J., Teusch, N., and Kuhn, U.: Controlling variables for the uptake of atmospheric carbonyl sulfide by soil, J. Geophys. Res., 104, 11577-11584, 1999.

Kettle, A. J.: Comparison of dynamic models to predict the concentration of a photochemical tracer in the upper ocean as a function of depth and time, Mar. Freshwater Res., 51, 289-304, 2000.

Kettle, A. J., Kuhn, U., von Hobe, M., Kesselmeier, J., and Andreae, M. O.: Global budget of atmospheric carbonyl sulfide: Temporal and spatial variations of the dominant sources and sinks, J. Geophys. Res., 107, 4658, doi:4610.1029/2002JD002187, 2002.

Kettunen, R., Saarnio, S., Martikainen, P. J., and Silvola, J.: Increase of $\mathrm{N}_{2} \mathrm{O}$ fluxes in agricultural peat and sandy soil under elevated $\mathrm{CO}_{2}$ concentration: concomitant changes in soil moisture, groundwater table and biomass production of Phleum pratense, Nutr. Cycl. Agroecosys., 74, 175-189, 2006.

Kjellstrom, E.: A three-dimensional global model study of carbonyl sulfide in the troposphere and the lower stratosphere, J. Atmos. Chem., 29, 151-177, 1998.

Kouwenberg, L. L. R., McElwain, J. C., Kurschner, W. M., Wagner, F., Beerling, D. J., Mayle, F. E., and Visscher, H.: Stomatal frequency adjustment of four conifer species to historical changes in atmospheric CO2, Am. J. Bot., 90, 610-619, 2003.

Kuhn, U., Ammann, C., Wolf, A., Meixner, F. X., Andreae, M. O., and Kesselmeier, J.: Carbonyl sulfide exchange on an ecosystem scale: soil represents a dominant sink for atmospheric COS, Atmos. Environ., 33, 995-1008, 1999.

Kurschner, W. M., Wagner, F., Visscher, E. H., and Visscher, H.: Predicting the response of leaf stomatal frequency to a future $\mathrm{CO}_{2}$-enriched atmosphere: constraints from historical observations, Geol.e Rundsch., 86, 512-517, 1997.

Lake, J. A. and Woodward, F. I.: Response of stomatal numbers to $\mathrm{CO}_{2}$ and humidity: control by transpiration rate and abscisic acid, New Phytol., 179, 397-404, 2008.
Mao, H., Talbot, R., Troop, D., Johnson, R., Businger, S., and Thompson, A. E.: Smart balloon observations over the North Atlantic: O3 data analysis and modelling, J. Geophys. Res., 111, D23S56, doi:10.1029/2005JD006507, 2006.

McLain, J. E. T., Kepler, T. B., and Ahmann, D. M.: Belowground factors mediating changes in methane consumption in a forest soil under elevated $\mathrm{CO}_{2}$, Global Biogeochem. Cy., 16, 1050, doi:1010.1029/2001GB001439, 2002.

Montzka, S. A., Calvert, P., Hall, B. D., Elkins, J. W., Conway, T. J., Tans, P. P., and Sweeney, C.: On the global distribution, seasonality, and budget of atmospheric carbonyl sulfide (COS) and some similarities to $\mathrm{CO}_{2}$, J. Geophys. Res., 112, D09302, doi:09310.01029/02006JD007665, 2007.

Norby, R. J., Hartz-Rubin, J. S., and Verbrugge, M. J.: Phenological responses in maple to experimental atmospheric warming and $\mathrm{CO}_{2}$ enrichment, Glob. Change Biol., 9, 1792-1801, 2003.

Norby, R. J., DeLucia, E. H., Gielen, B., Calfapietra, C., Giardina, C. P., King, J. S., Ledford, J., McCarthy, H. R., Moore, D. J. P., Ceulemans, R., De Angelis, P., Finzi, A. C., Karnosky, D. F., Kubiske, M. E., Lukac, M., Pregitzer, K. S., Scarascia-Mugnozza, G. E., Schlesinger, W. H., and Oren, R.: Forest response to elevated $\mathrm{CO}_{2}$ is conserved across a broad range of productivity, $\mathrm{P}$. Natl. Acad. Sci. USA, 102, 18052-18056, 2005.

Notholt, J., Kuang, Z., Rinsland, C. P., Toon, G. C., Rex, M., Jones, N., Albrecht, T., Deckelmann, H., Krieg, J., Weinzierl, C., Bingemar, H. G., Weller, R., and Schrems, O.: Enhanced upper tropical tropospheric COS: Impact on the stratospheric aerosol layer, Nature, 300, 307-310, 2003.

Oh, N. H. and Richter, D. D.: Elemental translocation and loss from three highly weathered soil-bedrock profiles in the southeastern United States, Geoderma, 126, 5-25, 2005.

Protoschill-Krebs, G. and Kesselmeier, J.: Enzymatic pathways for the consumption of carbonyl sulphide (COS) by higher plants, Bot. Acta, 105, 206-212, 1992.

Protoschill-Krebs, G., Wilhelm, C., and Kesselmeier, J.: Consumption of carbonyl sulphide by Chlamydomonas reinhardtii with different activities of carbonic anhydrase (CA) induced by different $\mathrm{CO}_{2}$ growing regimes, Bot. Acta, 108, 445-448, 1995.

Protoschill-Krebs, G., Wilhelm, C., and Kesselmeier, J.: Consumption of carbonyl sulfide (COS) by higher plant carbonic anhydrase (CA), Atmos. Environ., 30, 3151-3156, 1996.

Rogers, A. and Ellsworth, D. S.: Photosynthetic acclimation of Pinus taeda (loblolly pine) to long-term growth in elevated $p \mathrm{CO} 2$ (FACE), Plant Cell Environ., 25, 851-858, 2002.

Sandoval-Soto, L., Stanimirov, M., von Hobe, M., Schmitt, V., Valdes, J., Wild, A., and Kesselmeier, J.: Global uptake of carbonyl sulfide (COS) by terrestrial vegetation: Estimates corrected by deposition velocities normalized to the uptake of carbon dioxide $\left(\mathrm{CO}_{2}\right)$, Biogeosciences, 2, 125-132, 2005, http://www.biogeosciences.net/2/125/2005/.

Schafer, K. V. R., Oren, R., Lai, C.-T., and Katul, G. G.: Hydrologic balance in an intact temperate forest ecosystem under ambient and elevated atmospheric $\mathrm{CO}_{2}$ concentration, Glob. Change Biol., 8, 895-911, 2002.

Shepson, P. B., Bottenheim, J. W., Hastie, D. R., and Venkatram, A.: Determination of the relative ozone and pan deposition velocities at night, Geophys. Res. Lett, 19, 1121-1124, 1992. 
Simmons, J. S., Lemedtsson, L., Hultberg, H., and Hines, M. E.: Consumption of atmospheric carbonyl sulfide by coniferous boreal forest soils, J. Geophys. Res., 104, 11569-11576, 1999.

Sive, B. C., Zhou, Y., Troop, D., Wang, Y., Little, W. C., Wingenter, O. W., Russo, R. S., Varner, R. K., and Talbot, R.: Development of a cryogen-free concentration system for measurements of volatile organic compounds, Anal. Chem., 77, 6989-6998, 2005.

Sive, B. C., Varner, R. K., Mao, H., Blake, D. R., Wingenter, O. W., and Talbot, R.: A large terrestrial source of methyl iodide, Geophys. Res. Lett, 34, L17808, doi:10.1029/2007GL030528, 2007.

Solomon, S., Portmann, R. W., Garcia, R. R., Thomason, L. W., Poole, L. R., and McCormick, M. P.: The role of aerosol variations in anthropogenic ozone depletion at northern midlatitudes, J. Geophys. Res.-Atmos., 101, 6713-6727, 1996.

Steinbacher, M., Bingemer, H. G., and Schmidt, U.: Measurements of the exchange of carbonyl sulfide (OCS) and carbon disulfide (CS2) between soil and atmosphere in a spruce forest in central Germany, Atmos. Environ., 38, 6043-6052, 2004.

Steltzer, H. and Post, E.: Seasons and life cycles, Science, 324, 886-887, 2009.

Stenberg, P.: Correcting LAI-2000 estimates for the clumping of needles in shoots of conifers, Agr. Forest Meteorol., 79, 1-8, 1996.

Talbot, R., Mao, H., and Sive, B.: Diurnal characteristics of surface level $\mathrm{O}_{3}$ and other important trace gases in New England, J. Geophys. Res., 110, D09307, doi:10:1029/2004JD005449, 2005.

Taylor, J. R.: An introduction to error analysis: the study of uncertainties in physical measurements, in: Books in Physics, edited by: Commins, E. D., University Science Books, Sausalito, CA, 270 pp., 1982.

Turco, R. P., Whitten, R. C., Toon, O. B., Pollack, J. B., and Hamill, P.: OCS, stratospheric aerosols and climate, Nature, 283, 283286, 1980.

Varner, R. K., Crill, P. M., and Talbot, R. W.: Wetlands: a potentially significant source of atmospheric methyl bromide and methyl chloride, Geophys. Res. Lett., 26, 2433-2436, 1999.

Varner, R. K., Zhou, Y., Russo, R. S., Wingenter, O. W., Atlas, E., Stroud, C., Mao, H., Talbot, R., and Sive, B. C.: Controls on atmospheric chloroiodomethane $\left(\mathrm{CH}_{2} \mathrm{CII}\right)$ in marine environments, J. Geophys. Res., 113, D10303, doi:10.1029/2007JD008889, 2008.

Van Diest, H. and Kesselmeier, J.: Soil atmosphere exchange of carbonyl sulfide (COS) regulated by diffusivity depending on waterfilled pore space, Biogeosciences, 5, 475-483, 2008, http://www.biogeosciences.net/5/475/2008/.
Wagner, F., Dilcher, D. L., and Visscher, H.: Stomatal frequency responses in hardwood-swamp vegetation from Florida during a 60-year continuous $\mathrm{CO}_{2}$ increase, Am. J. Bot., 92, 690-695, 2005.

Watts, S. F.: The mass budgets of carbonyl sulfide, dimethyl sulfide, carbon disulfide, and hydrogen sulfide, Atmos. Environ., 34, 761-779, 2000.

Weiss, P. S., Andrews, S. S., Johnson, J. E., and Zafiriou, O. C.: Photoproduction of Carbonyl Sulfide in South-Pacific Ocean Waters as a Function of Irradiation Wavelength, Geophys. Res. Lett., 22, 215-218, 1995.

White, M. L., Russo, R. S., Zhou, Y., Mao, H., Varner, R. K., Ambrose, J., Veres, P., Wingenter, O. W., Haase, K., Stutz, J., Talbot, R., and Sive, B. C.: Volatile Organic Compounds in Northern New England Marine and Continental Environments during the ICARTT 2004 Campaign, J. Geophys. Res., 113, D08S90, doi:10.1029/2007JD009161, 2008.

$\mathrm{Xu}, \mathrm{X}$., Bingemer, H. G., and Schmidt, U.: The flux of carbonyl sulfide and carbon disulfide between the atmosphere and a spruce forest, Atmos. Chem. Phys., 2, 171-181, 2002, http://www.atmos-chem-phys.net/2/171/2002/.

Yi, Z., Wang, X., Sheng, G., Zhang, D., Zhou, G., and Fu, J.: Soil uptake of carbonyl sulfide in subtropical forests with different successional stages in south China, J. Geophys. Res., 112, D08302, doi:08310.01029/02006JD008408, 2007.

Zhou, L., Tucker, C. J., Kaufmann, R. K., Slayback, D., Shabanov, N. V., and Myneni, R. B.: Variations in northern vegetation activity inferred from satellite data of vegetation index during 1981 to 1999, J. Geophys. Res., 106, 20069-20083, 2001.

Zhou, L., Kaufmann, R. K., Tian, Y., Myneni, R. B., and Tucker, C. $\mathrm{J}$.: Relation between interannual variations in satellite measures of northern forest greenness and climate between 1982 and 1999 , J. Geophys. Res., 108, 4004, doi:10.1029/2002JD002510, 2003.

Zhou, Y., Varner, R. K., Russo, R. S., Wingenter, O. W., Haase, K. B., Talbot, R., and Sive, B. C.: Coastal water source of short-lived halocarbons in New England, J. Geophys. Res., 110, D21302, doi:10.1029/2004JD005603, 2005.

Zhou, Y., Mao, H., Russo, R. S., Blake, D. R., Wingenter, O. W., Haase, K., Ambrose, J. L., Varner, R. K., Talbot, R., and Sive, B.: Bromoform and dibromomethane measurements in the seacoast region of New Hampshire, 2002-2004, J. Geophys. Res., 113, D08305, doi:10.1029/2007JD009103, 2008. 